Assessment of Effectiveness of

Geologic Isolation Systems

\title{
Hydrogeologic Effects of \\ Natural Disruptive Events on \\ Nuclear Waste Repositories
}

S. N. Davis

University of Arizona

June 1980

Prepared for the

Office of Nuclear Waste Isolation

under its Contract with the

U.S. Department of Energy

Pacific Northwest Laboratory

Operated for the U.S. Department of Energy

by Battelle Memorial Institute 
NOTICE

This report was prepared as an account of work sponsored by the United States Government. Neither the United States nor the Department of Energy, nor any of their employees, nor any of their contractors, subcontractors, or their employees. makes any warranty, express or implied, or assumes any legal liability or responsibility for the accuracy, completeness or usefulness of any information, apparatus, product or process disclosed, or represents that its use would not infringe privately owned rights.

The views. opinions and conclusions contained in this report are those of the contractor and do not necessarily represent those of the United States Government or the United States Department of Energy.

\author{
PACIFIC NORTHWEST LABORATORY \\ operated by \\ BATTELLE \\ for the \\ UNITED STATES DEPARTMENT OF ENERGY \\ Under Contract DE-AC06-76RLO 1830
}

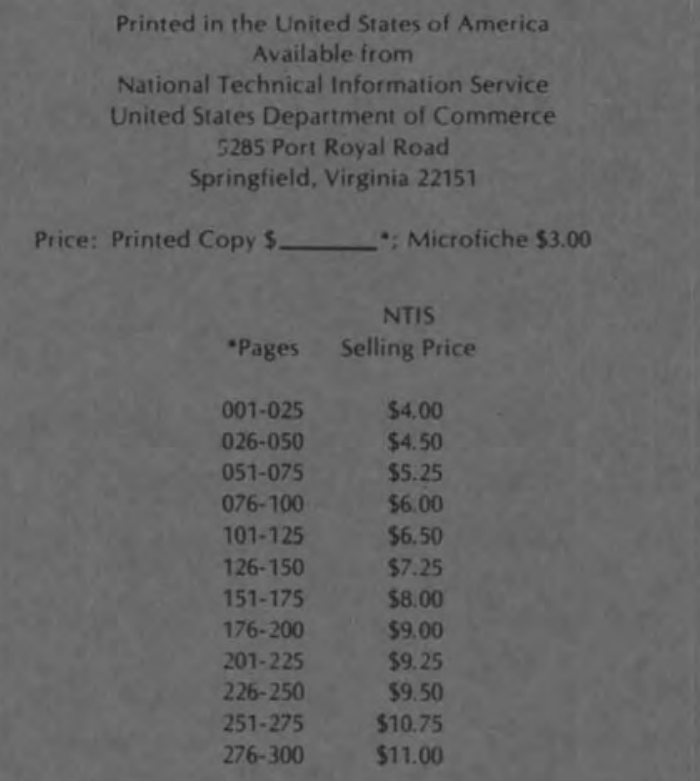


PNL -2858

UC -70

33679000493843

Assessment of Effectiveness of Geologic Isolation Systems

HYDROGEOLOGIC EFFECTS OF NATURAL

DISRUPTIVE EVENTS ON NUCLEAR

WASTE REPOSITORIES

S. N. Davis

University of Arizona

June 1980

Prepared for the

Office of Nuclear Waste Isolation

under its Contract with the

U.S. Department of Energy

Pacific Northwest Laboratory

Richland, Washington 99352 
, 


\section{PREFACE}

The generation of potentially hazardous radioactive waste products is associated with commercial nuclear power production in the United States. The Department of Energy (DOE), through the National Waste Terminal Storage (NWTS) Program and the Office of Nuclear Waste Isolation (ONWI), is seeking to develop nuclear waste isolation systems in geologic formations. These underground waste isolation systems will preclude contact with the biosphere of waste radionuclides in concentrations which are sufficient to cause deleterious impact on humans or their environments. Comprehensive analyses of specific isolation systems are needed to assess the post-closure expectations of the systems. The Assessment of Effectiveness of Geologic Isolation Systems (AEGIS) Program has been established for developing the capability of making those analyses.

The detailed assessment of the post-closure performance of nuclear waste repositories in geologic formations is among the analyses required for the system evaluation. This assessment is concerned with aspects of the nuclear program which previously have not been addressed. The nature of the isolation systems (e.g., involving breach scenarios and transport through the geosphere) and the great length of time for which the wastes must be controlled dictate the development, demonstration, and application of novel assessment capabilities. The assessment methodology must be thorough, flexible, objective, and scientifically defensible. Furthermore, the data utilized must be accurate, documented, reproducible, and based on sound scientific principles.

The current scope of AEGIS is limited to long-term, post-closure analyses. It excludes the consideration of processes that are induced by the presence of the wastes, and it excludes the consideration of nuclear waste isolation in media other than geologic formations. The near-field/near-term aspects of geologic repositories are being considered by ONWI/DOE under separate programs. They will be integrated with the AEGIS methodology for the actual site-specific repository safety analyses. 
The assessment of repository post-closure safety has two basic components:

- identification and analyses of breach scenarios and the pattern of events and processes causing each breach

- identification and analyses of the environmental consequences of radionuclide transport and interactions subsequent to a repository breach.

The Release Scenario task of AEGIS is charged with identifying and analyzing breach scenarios and their associated patterns of events and processes.

The Release Scenario task is concerned with evaluating the geologic system surrounding an underground repository and describing the phenomena which alone or in concert could perturb the system and possibly cause a loss of repository integrity. Output from the Release Scenario task will establish the boundary conditions of the geology and hydrology surrounding the repository at the time of an identified breach. These bounding conditions will be used as input for the consequence analysis task, which will employ soph isticated hydrological transport models to evaluate the movement of radionuclides through the groundwater system to the biosphere.

AEGIS has contracted with a number of consultants to obtain expert scientific opinion about the geologic processes which could affect an underground repository. The consultant teams were asked to specify processes and events which might affect potential repository sites and, if possible, to give rates and probabilities for those phenomena. The consultants have also been involved with the description of the system interactions and synergisms.

This report contains information obtained by one of the AEGIS consultants during the FY-1978 research effort. The research described in th is document is being continued during FY-1979 and FY-1980. Because of the ongoing nature of the Release Scenario methodology development effort, many of the results and conclusions outlined in this report are subject to change upon completion of additional research and analyses. The information contained in this report is based upon the expert opinion of an individual consultant and should be treated as such. 


\section{EXECUTIVE SUMMARY}

This report describes some possible hydrogeologic effects of disruptive events that may affect repositories for nuclear waste. Although the importance of human activities in possible containment failure is apparent to all students of the problem, this report concentrates on the effects of natural events. A very large number of combinations of natural events can be imagined, but this report covers only those events which are judged to be most probable. Furthermore, this report excludes consideration of waste-induced effects.

Failure of the containment of deeply buried radioacive waste, if it occurs, would most likely involve some transport of radionuclides by ground water. The prediction of the future ground-water motion is, therefore, of prime importance. Although sorption characteristics of the media are of primary importance in radionuclide transport, the objective of the present review is to discuss the nonchemical aspects of natural disruptive events. Of the nonchemical variables, the permeability of the material is most difficult to estimate accurately for a given transport problem. Even if present field conditions were known perfectly, future geologic processes, such as compaction, weathering, fracturing, and cementation, could easily change current values of permeability by several orders of magnitude. Reasonable values are given in this report for various natural materials, but these values must be taken with caution. They represent only the median value in a set of log-normally distributed values from a given formation.

Effective porosity values, which also govern the flow velocities and are inversely proportional to those velocities, vary between about 0.001 and 0.2 $(0.1 \%$ and $20 \%)$ for most water-bearing materials. Because effective porosity has a normal distribution in samples from a given formation, moderately close estimates of the effective porosity can be obtained with only a limited number of field determinations. Dispersion, which is another critical factor in transport equations, is difficult to estimate. It has been common knowledge 
for many years that laboratory determinations of dispersivity are almost meaningless when applied to field situations. Generally, field values are at least one or two orders of magnitude larger than corresponding laboratory determinations would suggest. Unfortunately, good field determinations of dispersivity are very scarce.

There are numerous disruptive events that could cause a containment failure in a nuclear waste repository. Faulting, dissolution of rocks, miscellaneous fracturing, and rapid changes of the ground-water regimen are the natural events considered most likely to induce undesired transport of radionuclides. Most disruptive events will cause some new ground-water flow patterns to develop in response to increased permeability of the rocks or increased amount of ground water. Increases in ground water may be due to increases in water available for recharge. As a first approximation, natural disruptive events can be assumed to produce permeable zones that allow instantaneous injection of contaminated water into adjacent permeable rocks. This assumption is very conservative and should only be used when details of the natural system are not available for more realistic models.

Permeability increases produced by faulting have been a cause of concern with respect to the integrity of a waste repository. However, contrary to many published reports, faults do not necessarily increase the permeability of rocks that are affected. Many active faults in California have been documented to be ground-water barriers. Furthermore, recent faults in other regions common ly show evidence of local decreases of permeability. In general, faults that offset nonindurated sediments tend to form hydraulic barriers, and only geologically young normal faults traversing older brittle rock are always zones of high permeability.

Dissolution of anhydrite, gypsum, limestone, dolomite and salt can form collapse features, which in turn may disrupt nuclear repositories. Dissolution may result from the entry of water via poorly sealed shafts and boreholes. Dissolution may also occur where the regional flow of ground water comes into contact with the evaporite. The dissolution may be relatively slow, with a corresponding slow settling and failure of overlying material. Occasionally the dissolution produces subsurface cavities that collapse suddenly and sometimes catastrophically. 
Dissolution with subsequent collapse is the most probable form of containment failure for repositories in bedded salt and salt domes.

Nontectonic fracturing of rock may be associated with large lancislides, subsidence of alluvial basins, and impact and explosion events. Proper site location should avoid most areas of nontectonic fracturing.

Rapid changes of the ground-water regimen are particularly difficult to predict. In general, if one takes the elevation of the local recharge area and assumes that ground water fills all pore spaces to the surface, and if the exit head is assumed to be stable, then most regional ground-water gradients in humid areas are not even doubled. In arid regions, in contrast, the gradients may be more than tripled. Because transport velocities are almost everywhere proportional to the gradients, the rates of movement of radionuclides will be increased accordingly. The most serious problem that could come from changes in the ground-water regimen appears to be a shortening of the groundwater flow path. If ground-water levels increase in elevation until the water is near the surface, then long, regional flow paths of contaminant travel may become short, local paths. Stated in another way, a large increase in the quantity of local ground water may cause a more direct and rapid movement of contaminants to the surface.

The disruptive events discussed above are placed into four geologic settings within this report. Although the geology is not specific to given repository sites that have been considered by other agencies, the geology has been generalized from actual field data and is, therefore, considered to be physically reasonable. The geologic settings considered are: 1) interior salt domes of the Gulf Coast, 2) bedded salt of southeastern New Mexico, 3) argillaceous rocks of southern Nevada, and 4) granitic stocks of the Basin and Range Province. Log-normal distributions of permeabilities of rock units are given for each region. 


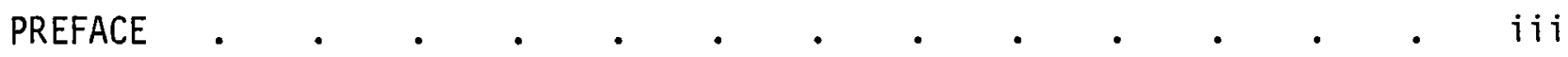

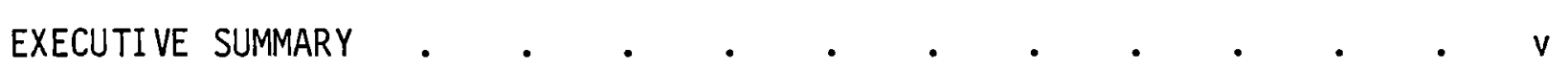

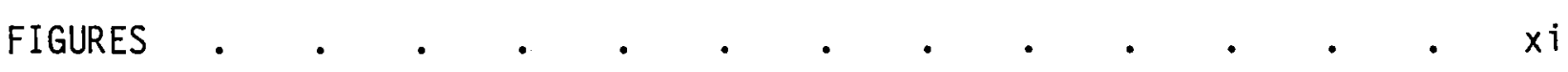

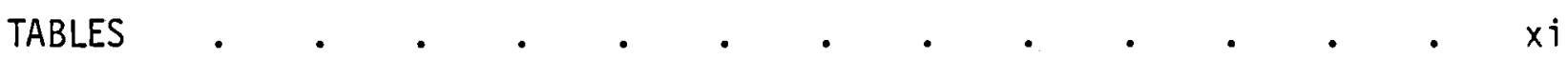

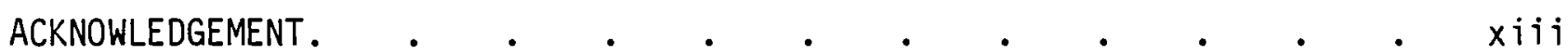

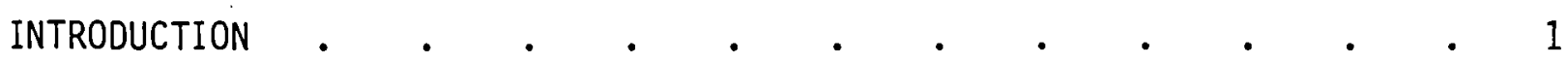
POROSITY AND PERMEABILITY OF NATURAL MATERIALS . . . . . . 2 POROSITY • • • . . . . . . . . . . . 2

PERMEABILITY •

REGIONAL FLOW PATTERNS • • • • • • • . • • 8 DISRUPTIVE EVENTS $• . \quad$ •

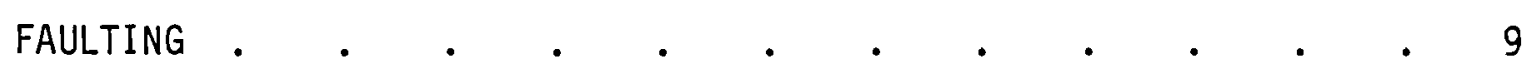

DISSOLUTION OF ROCK FORMING MINERALS

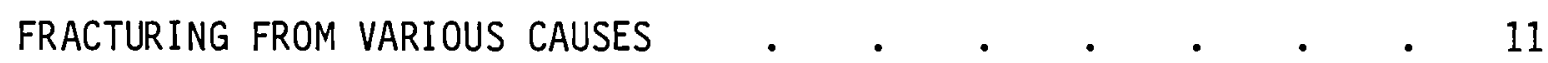

RAPID CHANGES OF HYDRAULIC REGIMEN • • • • • • • . 12 POSSIBLE HYDROLOGIC EFFECTS OF DISRUPTIVE EVENTS • • • • • • 13 GULF COAST SALT DOMES BEDDED SALT OF THE SOUTHWEST • • . . . . . . . 20 SHALE IN THE bASIN AND RANGe PROVINCE . . . . . . . . 24 GRANITIC STOCKS IN THE BASIN AND RANGE PROVINCE. . $. \quad . \quad .28$ HYDRAULIC FRACTURING REFERENCES . . . . . . . . . . . . 31 


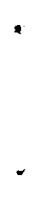




\section{FIGURES}

1. Statistical Distributions of Porosity and Permeability of 44 Samples of Navajo Sandstone.

2. Possible Relationships Among Rainfa11, Recharge, and Regional Hydraulic Gradients . . . . . . . . . . . . 14

3. Generalized Section Through an Interior Gulf Coast Salt Dome $\quad$ - 16

4. $\log _{10}$-Probability Distributions of Permeabilities of Various Sedimentary Materials near Interior Gulf Coast Salt Domes . • 17

5. Log10-Probability Distribution of Bed Thicknesses in Miocene and

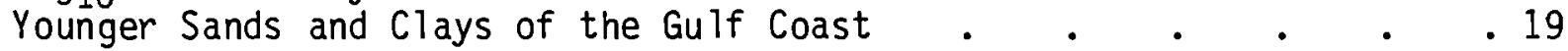

6. Cross Section Through a Possible Nuclear Repository in Southeastern New Mexico

7. Log10-Probability Distributions of Permeabilities of Various Sedimentary Materials in Southeastern New Mexico . . . . . . . 23

8. Hypothetical Cross Section Through Argillaceous Rocks in the Nevada Test Site.

9. Log10-Probability Distributions of Permeabilities of Various Geologic Units in the Basin and Range Province in Southern Nevada . 27

10. Cross Section Through a Hypothetical Nuclear Repository in a Granitic Stock, Basin and Range Province

\section{$\underline{\text { TABLES }}$}

1. Representative Porosities of Natural Materials . . . . . . 3

2. Approximate Equivalence of Units of Permeability and Fluid Conductivity

3. Representative Values of Permeability of Natural Materials . $\quad$ - 5 


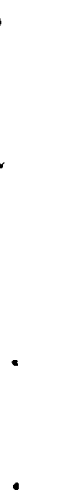

· 


\section{ACKNOWLEDGEMENT}

Th is research was supported by the Waste Isolation Safety Assessment Program (WISAP) conducted by Pac ific Northwest Laboratory. The program was sponsored by the Office of Nuclear Waste Isolation, managed by Battelle Memorial Institute for the Department of Energy under Contract DE-ACO6-76RL0-1830. On 1 October 1979, WISAP became the Assessment of Effectiveness of Geologic Isolation Systems (AEGIS) Program and the Waste/Rock Interactions Technology (WRIT) Program. This report was issued by AEGIS. 


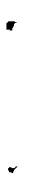




\section{INTRODUCTION}

The assessment of hazards from deeply buried nuclear repositories must include consideration of several possible mechanisms of containment failure. One of the most difficult mechanisms to assess is the upward transport of radionuclides into the biosphere by slowly moving ground water. This mechanism is, moreover, one of the most likely failure modes, particularly if some disruptive event such as faulting affects the repository.

The purpose of this report is to review some of the hydrogeologic aspects of containment failure, especially in relation to natural disruptive events. Attention will be focused on geologic environments typical of salt domes in the Gulf Coast, bedded salt in Texas, Oklahoma and New Mexico, and various media found in the Nevada Test Site. Although this report will not concentrate on site-specific details, the hydrogeologic properties that are discussed, insofar as possible, will be based on actual field investigations. 


\section{POROSITY AND PERMEABILITY OF NATURAL MATERIALS}

\section{POROSITY}

In simplest terms, total porosity is the volume fraction of pore space in an otherwise solid sample of rock. It is most commonly expressed as a percentage. An average sample of a rock which has a porosity of $25 \%$ would have 3 parts solid material to 1 part void space. Effective porosity is volume fraction of the rock occupied by interconnected pores which allow the migration of subsurface fluids. For coarse sand, the total porosity and the effective porosity of a given sample are almost equal. For vesicular basalt, the total porosity may be more than twice as great as the effective porosity.

Natural materials are not homogeneous with respect to porosity. Extensive studies of rock cores sampled from the same formation and brought into the laboratory suggest that values of porosity measured in the laboratory are distributed statistically in a normal manner (Bennion and Griffiths 1966; Davis 1969). As will be explained in the next section, however, the statistical distribution is affected strongly by the size of the sample considered.

Porosities of natural materials have been tabulated by many authors, including Davis (1969) and Manger (1963). Representative values taken from these and other publications are given in Table 1.

\section{PERMEABILITY}

Permeability is a measure of the ease with which fluids pass through a porous material. Permeability is a property of the solid material and is independent of the gravitational field and the properties of the fluid. Permeability, $k$, is determined experimentally by measuring the variables in the following equation:

$$
k=-\frac{Q}{A} \frac{\mu}{\rho g}\left(\frac{\partial h}{\partial s}\right)^{-1}
$$


TABLE 1. Representative Porosities of Natural Materials

METAMORPHIC AND IGNEOUS ROCKS, UNWEATHERED $\%$

Granite at depth, no microfractures 0.2

Granite at shallow depth with microfractures 0.8

Diabase, no microfractures 0.1

Schist, some microfractures 0.6

Basalt in dike 2.1

Basalt, central part of lava flow 5.5

Basalt, top part of lava flow 49.2

Tuff, pumiceous $\quad 40.0$

Tuff, welded 14.0

$\begin{array}{ll}\text { Pumice } & 87.3\end{array}$

$\begin{array}{ll}\text { Marble, unfractured } & 0.6\end{array}$

METAMORPHIC AND IGNEOUS ROCKS, WEATHERED

Weathered schist at depth of 35 feet 42

Slightly weathered granite 15

Highly weathered basalt (residual soil) 51

\section{SEDIMENTARY ROCKS}

Arkose $\quad 14.4$

Chalk 29.2

Chert $\quad 3.8$

Dolomite 11.9

Limestone, Cenozoic $\quad 21.6$

Limestone, Paleozoic 6.3

Sandstone, dense 11.2

Sandstone, slightly indurated $\quad 27.4$

Shale, Cenozoic 21.1

Shale, slightly metamorphosed $\quad 5.2$

NONINDURATED SEDIMENTS

Clay, marine

Clay, silty, alluvial

48.5

Silt, loess

Silt, alluvium

41.1

50.0

Sand, alluvium

39.4

Sand, fine grained alluvium

41.0

Sand, coarse grained alluvium

51.3

Sand, from sand dune

33.8

35.8 
in which $Q$ is the volume of fluid discharged per unit time through a crosssection having an area $A, \mu$ is the dynamic viscosity of the fluid, $\rho$ is the density of the fluid, $g$ is the acceleration of gravity, and $2 h / \partial s$ is the fluid gradient in the direction of flow, s.

Permeability has the dimensions of length squared and should not be confused with fluid conductivity, which has the dimensions of length divided by time. A common expression for fluid conductivity, $K$, is:

$$
K=-\frac{Q}{A}\left(\frac{\partial h}{\partial s}\right)^{-1}
$$

in which the other symbols are the same as above. The approximate equivalence of various units of permeability and fluid conductivity is given in Table 2. The unit of permeability called the darcy will be used in this report.

TABLE 2. Approximate Equivalence of Units of Permeability and Fluid Conductivity

$$
\begin{aligned}
& 1 \text { darcy }=9.87 \times 10^{-9} \mathrm{~cm}^{2}=1.062 \times 10^{-11} \mathrm{ft}^{2} \\
& 1 \text { meinzer }=0.134 \mathrm{ft} / \text { day }=4.72 \times 10^{-5} \mathrm{~cm} / \mathrm{sec} \\
& 1 \mathrm{~m} / \text { day }=3.28 \mathrm{ft} / \text { day }=1.15 \times 10^{-3} \mathrm{~cm} / \mathrm{sec} \\
& \text { The following values are for water at about } 20^{\circ} \mathrm{C} \\
& 1 \text { me inzer }=5.5 \times 10^{-2} \text { darcy } \\
& 1 \text { darcy }=18.2 \text { meinzer units } \\
& 1 \mathrm{~cm} / \mathrm{sec}=1035 \text { darcys }
\end{aligned}
$$$$
1 \text { meinzer }=0.134 \mathrm{ft} / \text { day }=4.72 \times 10^{-5} \mathrm{~cm} / \mathrm{sec}
$$$$
\text { The following values are for water at about } 20^{\circ} \mathrm{C}
$$

Permeability is commonly considered a constant property of natural material. This assumption is a useful approximation for many purposes. Nevertheless, both short-term and long-term changes do take place. In very dense rocks, most permeability results from widely spaced fractures, which may have apertures of less than 10 micrometers. Permeabilities of such rocks are very sensitive to earth tides, earthquakes, temperature changes, and other sources of small but significant strain in the rocks. Rocks and sediments having clay minerals will change permeability in response to the shrinking or swelling of 
the clays. Generally, clayey material will be most permeable to dry air and least permeable to fresh water. Brine will produce permeability values that lie between those for fresh water and air. Dissolution of rock-forming minerals may greatly increase the permeability of dense, fractured rock. The effects of dissolution may be rapid as in the case of gypsum, moderately slow as in the case of calcite and dolomite, or very slow as in the case of quartz.

As well as accounting for the time-dependent changes in permeability in the field situation, hydrogeologic studies must take into account the fact that laboratory measurements may not duplicate field situations. As a minimum requirement, laboratory samples must be placed under confining pressures equal to the pressures at depth in the zone of interest. Rock samples are commonly many times more permeable in their unconfined condition than in their confined condition.

Permeabilities of natural materials range through at least 12 orders of magnitude. Further attention will be given to permeabilities of specific materials later in this report. Nevertheless, a few representative values are given for early reference in Table 3.

TABLE 3. Representative Values of Permeability of Natural Materials (values in darcys)

Description

$\begin{array}{lll}\text { Chert, Precambrian } & 1.1 \times 10^{-7} & \text { Sanyal et al. } 1971 \\ \text { Mica schist } & 2.1 \times 10^{-6} & \text { Davis } 1969 \\ \text { Rock salt } & 7.3 \times 10^{-6} & \text { Davis } 1969 \\ \text { Gypsum } & 3.1 \times 10^{-5} & \text { Sanyal et al. } 1971 \\ \text { Silt, Pascagoula formation } & 3.8 \times 10^{-5} & \text { Johnson and Ludwig } 1965 \\ \text { Sandstone, Catahoula formation } & 5.5 \times 10^{-4} & \text { Johnson and Ludwig } 1965 \\ \text { Tuff, friable } & 1.4 \times 10^{-3} & \text { Davis } 1969 \\ \text { Dolomite } & 1.6 \times 10^{-2} & \text { Davis } 1969 \\ \text { Sandstone, friable } & 3.6 \times 10^{-1} & \text { Davis } 1969 \\ \text { Sand, alluvial } & 2.2 & \text { Davis } 1969 \\ \text { Sand, coarse } & 55.0 & \text { Davis } 1969 \\ \text { Limestone, Biscayne aquifer } & 1600 & \text { Davis } 1969\end{array}$


If several samples from a single geologic formation are taken to the laboratory and their permeabilities are measured, the values obtained will have a log-normal statistical distribution (Figure 1 ). Also, field tests tend to show log-normal distributions (Davis 1969; Stewart 1966; Mundi and Wallace 1973). However, as Rats and Chernyashov (1967) have pointed out, the type of distribution is influenced strongly by the sample dimensions (such as diameter of core or area of influence of an aquifer test) and the spacing of discontinuities (or distance between pores, joints, faults, etc.). For any given pattern of discontinuities repeated in space, the distributions go from heterogeneous, to log-normal, to normal, to quasihomogeneous as sample dimensions increase. 


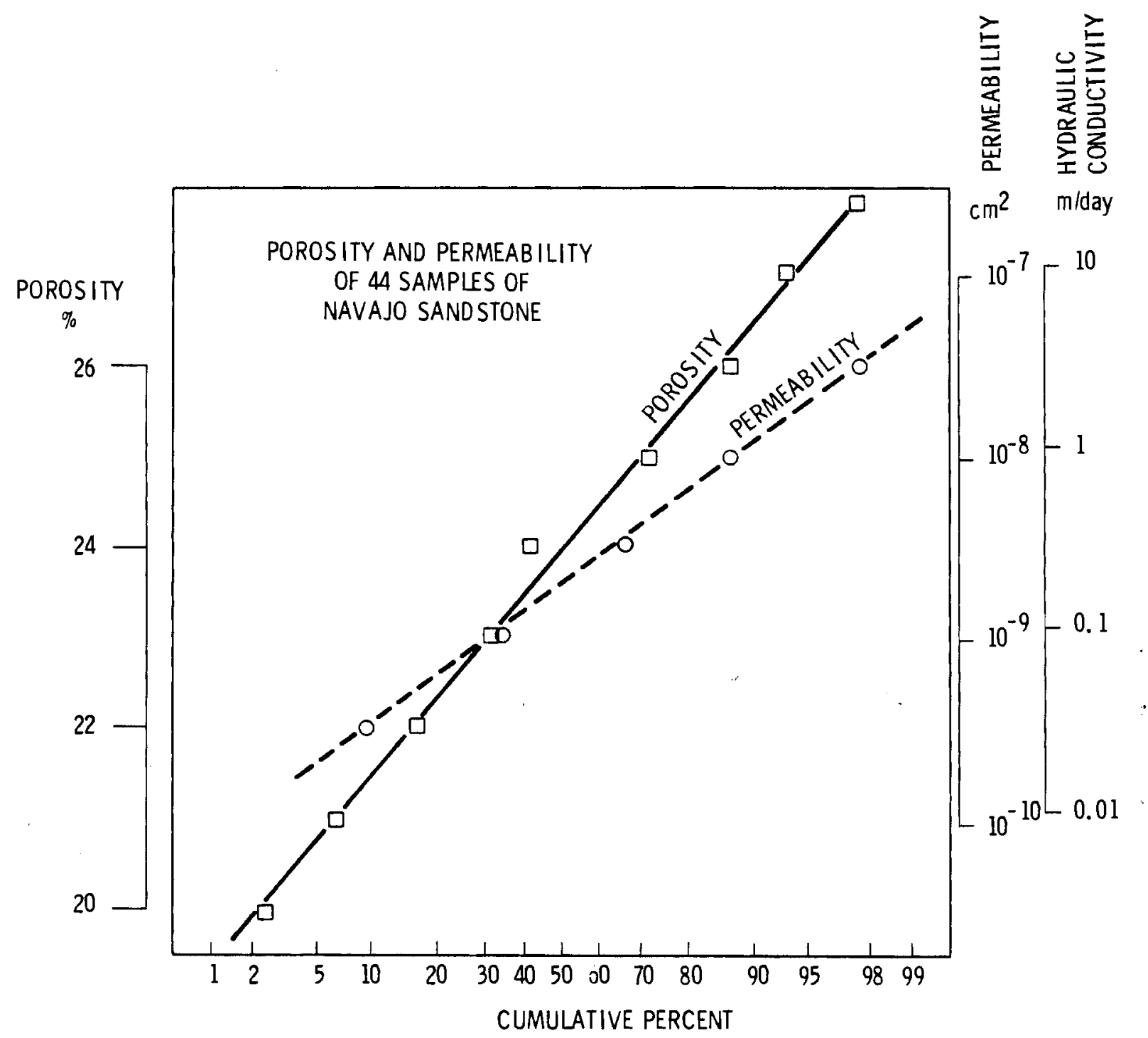

FIGURE 1. Statistical Distributions of Porosity and Permeability of 44 Core Samples of Navajo Sandstone from Arizona 


\section{REGIONAL FLOW PATTERNS}

The effects of disruptive events must be assessed using realistic flow patterns. For example, the creation of a permeable zone from the repository to the surface does not, except for gases, automatically suggest an escape of radionuclides at the surface. To the contrary, in the arid Southwest most potential repository sites are in areas of recharge where the movement of water is downward. A permeable zone connecting the repository to the surface will most likely allow only a slight increase in recharge. Therefore, no great adverse hydrologic effects may be expected, unless the newly created permeable zone intersects aquifers of significant transmissivities.

Regional flow patterns, together with a knowledge of the variation of hydraulic gradients, can be combined with known or assumed hydraulic gradients and effective porosities to calculate approximate average water velocities. These average water velocities are used in various equations to estimate the direction, velocity, and concentrations of radionuclides being transported by the ground water. Refinement of transport models requires data on sorption (distribution coefficients) as well as dispersion characteristics of the solid matrix. Although not discussed in detail here, an inspection of the various equations will indicate that transport velocities are most sensitive to assumed permeabilities and distribution coefficients. Although hydraulic gradients, effective porosities, and dispersion coefficients are also very important, both permeabilities and distribution coefficients can vary easily through many orders of magnitude in natural systems, whereas the other factors can be commonly estimated to an accuracy of one order of magnitude or less. 


\section{DISRUPTIVE EVENTS}

For this report, a disruptive event is considered to be any event, whether slow or abrupt, which will significantly disrupt the present groundwater flow. Although man-made disruptions of the flow regimen are numerous, they will be given only secondary consideration. Very slow changes of the ground-water regimen can be caused by normal processes of erosion, which will lower hydraulic heads at discharge points. Unloading by erosion could also increase the permeabilities and porosities of rocks in the subsurface. Dense granites, gneisses, schists, diorites, gabbros, and other plutonic and metamorphic rocks would be affected most drastically. Although normal erosion is a slow process, it might be considered a disruptive "event." However, its effects will not be discussed in detail in this report.

\section{FAULTING}

The hydrogeologic effects of faulting will vary according to the fundamental nature of the faulting process and according to the mechanical characteristics of the material being faulted. Maximum permeabilities will be developed in the upper plates of thrust faults and along normal faults. Strike-slip faults, such as the San Andreas and Hayward faults in California, are not noted for production of high permeabilities. Wells in the San Andreas fault zone south of San Francisco are not usually productive. There is even some suggestion that the average permeabilities of rocks are somewhat lower in this zone than in adjacent areas. Moreover, reservoirs on this fault zone show no indication of leakage that could be related to a rubbly zone of high regional permeability. The Hayward fault has long been known to be a partial subsurface barrier to ground-water movement in the Fremont area. Numerous other examples of hydrologic barriers formed by faults are known throughout central and southern California.

Faulting in alluvial aquifers often greatly reduces the horizontal permeability of the aquifers by producing gouge, localizing cementation by secondary minerals, reorienting flat clasts with their long axis parallel with 
the fault plane and, probably most important, offsetting permeable beds so that they are set against nonpermeable zones.

Faulting in brittle rocks will increase local permeabilities by several orders of magnitude. Inflows of large volumes of water into mines and tunnels along fault zones are widely reported in the literature. In fact, for practical purposes, some of these zones approach infinite permeabilities. Despite the large initial flows of water, mud, and rocks into tunnels from some of the most permeable fault zones, the flow commonly decreases rapidly, due to $1 \mathrm{imi-}$ ted storage of ground water in the fracture zones. As a broad generalization, brittle fracture is most likely in rocks of very low porosity. This type of fracturing will produce strong fragments that tend to help prop the fractures open. However, even when highly fractured, these rocks will rarely store water in more than $5 \%$ of the ir total volume. Thus, the total amount of water contained in these permeable zones may be relatively small.

\section{DISSOLUTION OF ROCK-FORMING MINERALS}

Due to a variety of natural or man-made processes, the dissolution of rock-forming minerals may depart from the usual slow, natural rates. Although salt is most vulnerable, other rock-forming minerals, such as calcite, dolomite and gypsum, could be affected significantly within periods of a few years. If the temperature of the groundwater is increased, as it might be in the vicinity of a repository, even rock-forming silicates, including quartz, will go into solution at significant rates.

Dissolution will, of course, increase the local permeability by many orders of magnitude, provided that the rock has the strength to maintain open cavities, and provided that secondary minerals do not clog newly formed pores. The resultant increase in the flow of ground water will, in turn, increase the rate of dissolution, so that the process is self reinforcing under many natural situations.

The process of dissolution could tend to be self healing. If insoluble residues make up a significant percentage of the entire rock volume, then the 
residues could eventually migrate and clog openings in the rock. Also, in the case of heat-induced dissolution of silicates, the silica will become supersaturated and will be deposited as opal or chert as the water migrates away from the heat source into cooler rocks. Another self-healing process could be brought about by mixing two unlike waters. For example, water with a low Eh containing $\mathrm{Fe}^{2+}$ could mix with recently infiltrated surface water containing dissolved oxygen. As a result, $\mathrm{Fe}(\mathrm{OH})_{3}$ will be precipitated and will clog pore space. Other, more complicated reactions involving carbonate minerals could also take place. Finally, concentrations of stress will increase the solubility of minerals. Thus, minor fractures may heal due to dissolution of minerals at pressure points and redeposition of the same minerals in zones of low pressure. The low pressure zones will be the widest spots along the fracture.

Regional climatic changes can significantly affect the dissolution of minerals in the subsurface. Cool, pluvial periods will increase the amount of water available for dissolution. Also, the capacity of the water to dissolve carbonate minerals will be increased because of the increased $\mathrm{CO}_{2}$ solubility in the cold water.

\section{FRACTURING FROM VARIOUS CAUSES}

Fractures in the material surrounding a repository could form from a variety of causes. Stresses giving rise to failure can be related to differential compaction of sedimentary materials, deep desiccation of sediments, changes of temperature, changes of mineral type (such as the transition from anhydrite to gypsum), short-term stresses from nearby earthquakes, subsidence caused by ground-water pumping, and many other phenomena (Davis 1978).

If the fractures are caused by tensile failure and form open spaces, they are called fissures. Fissures are most common in nonindurated sediments in the valleys of the Southwest. They are particularly common in California, Arizona and Nevada. Typically, fissures open to widths of from 5 to $50 \mathrm{~mm}$ and are afterwards enlarged by water erosion as surface runoff cascades into the 
fissures. Several lines of reasoning, as we 11 as limited subsurface information, suggest strongly that the fissures may extend downward at least 100 meters from the surface. Infilling by sediment may eventually tend to produce a near-vertical barrier of tabular shape. Nevertheless, for periods of from 2 to 10 years the fissures accept impressive amounts of water and sediment and undoubtedly form efficient channels for ground-water recharge. Some fissures having lengths of less than 100 meters have received more than $10^{7}$ liters of water during a single rain storm.

Along the Gulf Coast in the vicinity of Houston, ground-water pumping has evidently activated or accelerated the movement of Pleistocene growth faults. The activity along these faults extends downward for tens, if not hundreds, of meters. Some suggestion exists that these reactivated faults may serve as partial barriers to horizontal ground-water movement.

\section{RAPID CHANGES OF HYDRAULIC REGIMEN}

Several potential causes exist for abrupt changes in subsurface hydraulic heads and gradients. Those changes thought to be most disruptive are abrupt increases in hydraulic heads. Such increases could lead to flooding of repositories and, in extreme cases, even to the phenomenon of hydraulic fracturing. Increases in hydraulic gradients could also be troublesome. They might lead to landslide-type failures or to greatly increased dissolution phenomena caused by large increases in the ground-water flux.

Changes in the hydraulic regimen could be produced by a variety of causes, including local ponding of rivers, changes of ocean levels related to world-wide glaciation, erosion or sedimentation of river valleys, and changes in available moisture caused by climatic changes or by changes in human culture. Also, in northern regions, the reexpansion of continental ice sheets could cause very high subglacial pressures to be transmitted to aquifers. 


\section{POSSIBLE HYDROLOGIC EFFECTS OF DISRUPTIVE EVENTS}

The following section covers some of the possible disruptive events which may take place in settings similar to those at proposed sites for nuclear repositories in the southern and southwestern United States. Although the geologic cross sections that are presented are hypothetical, they are generally patterned after actual geologic settings in northern Louisiana and eastern Texas, southeastern New Mexico and southern Nevada.

One troublesome question which will be difficult to answer precisely concerns the nature of the hydrogeologic effects produced by climatic changes. Because of the complex nature of the relationships among soil moisture, plant growth, sunlight, temperature, wind, precipitation, and changes in local and regional base levels, the ground-water recharge and subsequent changes in hydraulic gradients cannot be predicted on a short-term basis. It would be even more problematic to make predictions for periods of several thousands of years. A qualitative representation of possible changes of hydraulic gradients with precipitation is given in Figure 2. Average recharge over a wide area is assumed, rather than local recharge in favored locations such as isolated ephemeral stream beds. In highly localized areas, recharge could increase faster than the increase in rainfall. The limiting line in the upper figure with a $1: 1$ slope could represent precipitation falling on highly fractured bedrock along a fault or on blocky rock in a talus slope. In general, however, the true lines for any given region will fall well below the 1:1 slopes in both diagrams. More specific comments are included under subsections which follow.

\section{GULF COAST SALT DOMES}

A number of salt domes in Texas, Louisiana, and Mississippi have been considered for possible repository sites for nuclear waste. One of these domes (Tatum dome in Mississippi) has already received radioactive material from nuclear detonations in the dome several years ago. The domes under consideration for repositories are interior domes. These domes are generally about 100 to 200 miles inland from the shoreline of the Gulf of Mexico. 


\section{RECHARGE}
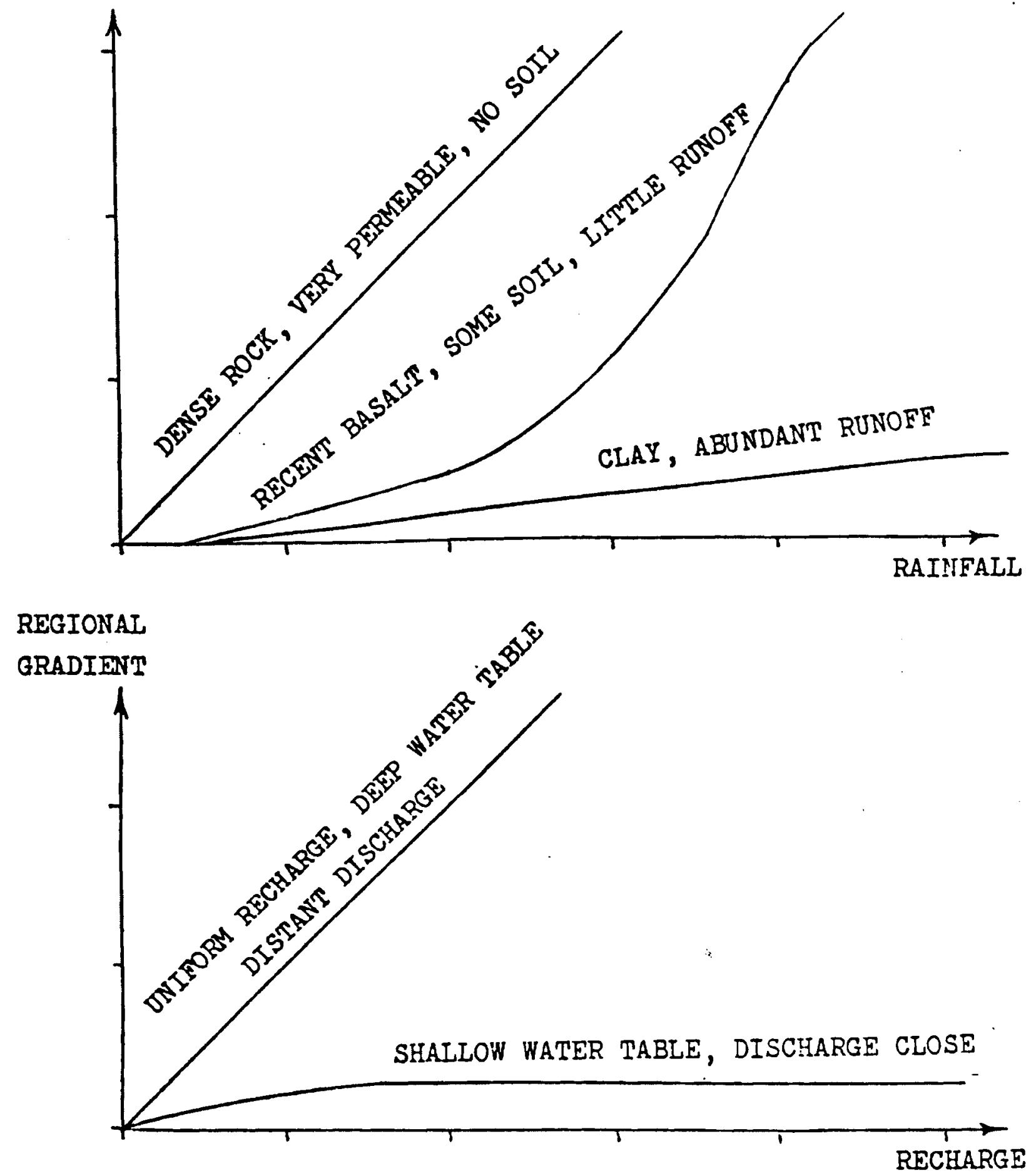

FIGURE 2. Possible Relationships Among Rainfall, Recharge, and Regional Hydraulic Gradients 
The interior domes have formed by the upward penetration of salt through 3 to $6 \mathrm{~km}$ of Jurassic and Cretaceous sedimentary rocks. The youngest strata penetrated by the domes are lower Tertiary sands and clays. The domes of possible interest end primarily in Eocene sediments and are overlain by upper Eocene, 0ligocene and, in Mississippi, by Miocene sediments. A thin and discontinuous layer of Pleistocene clays and sands is present at the surface above most of the domes. In terms of the possible transport of radionuclides, the Eocene sands such as the Wilcox and Sparta Formations and the Miocene Catahoula Formation are probably the most critical aquifers.

The interior domes are thought to be mostly stable and are not extruding or moving upward at the present time. The most likely form of containment failure involves human intrusion and solution collapse. Sometime in the future, human activity may pierce the natural protective cover of the dome and allow slow circulation of water in the dome. Eventually, dissolution of the salt will lead to solution collapse. This sequence of events will allow movement of radionuclides into adjacent aquifers, as shown schematically in Figure 3. The inverted "T" is the suggested position of a repository. The actual size of the final repository would probably be larger than the figure indicates, and the repository might have two or three different levels. The arrows suggest possible paths of water movement after containment failure. The hydraulic gradient that is given is the ground-water gradient in the sandstone aquifer. Once radionuclides enter the aquifer, their movement and concentrations are governed by the following factors: time; decay rates of the nuclides; sorption characteristics, permeabilities, dispersivities, and effective porosities of the solid media; densities and viscosities of the various masses of water; and hydraulic gradients.

Reasonable permeabilities for typical sediments near salt domes are shown in Figure 4 . Vertical values are in $\log _{10}$ of darcys. Horizontal values are the probabilities that a value of permeability equal to or smaller than the one given will be encountered. Permeabilities of less than 0.1 darcy are from laboratory measurements of cores. Other values, where possible, have come from various types of field tests, including aquifer tests and packer tests. Reliability of data varies widely; permeabilities from this diagram should 

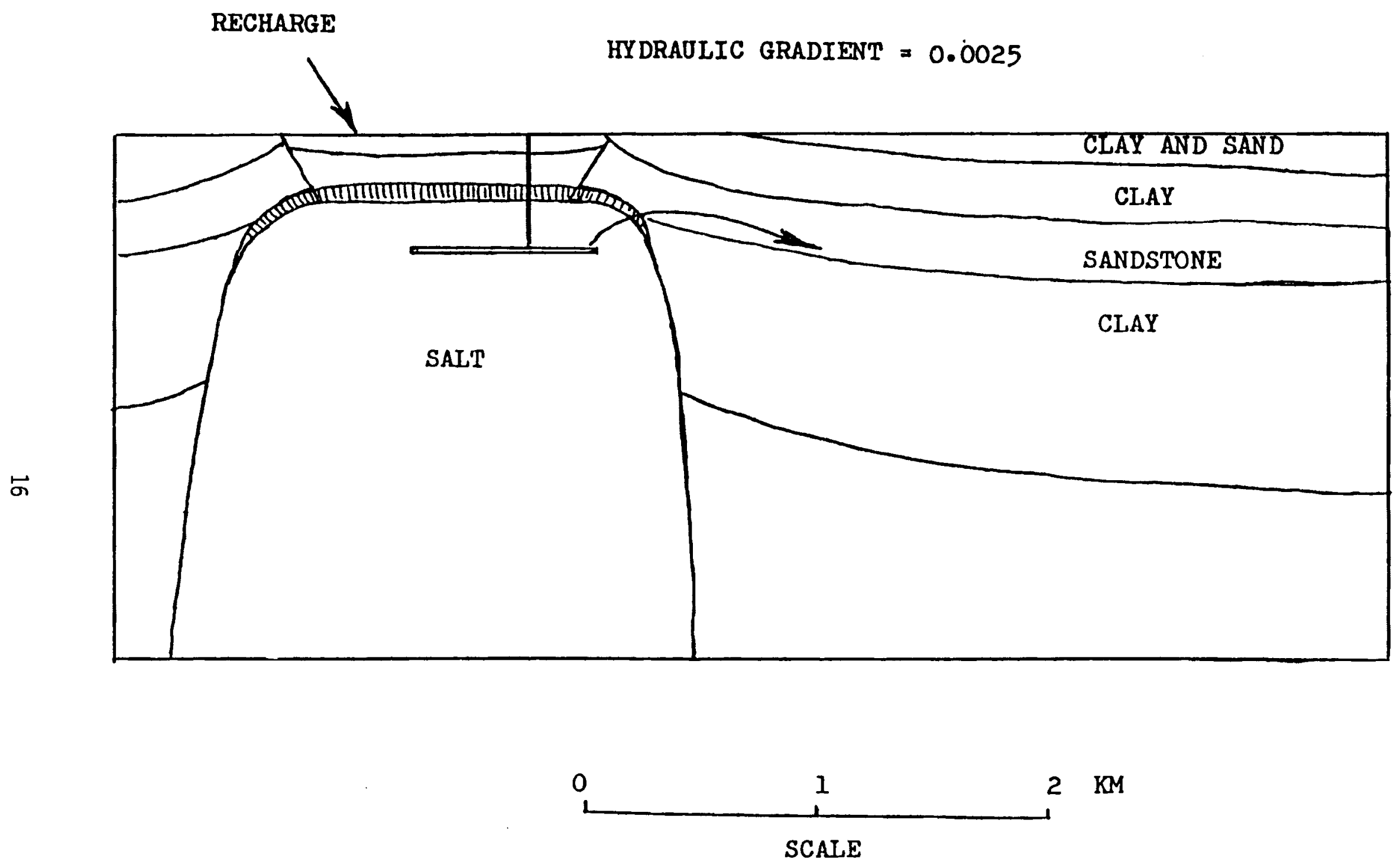

FIGURE 3. Generalized Section Through an Interior Gulf Coast Salt Dome (horizontal and vertical scales are identical) 


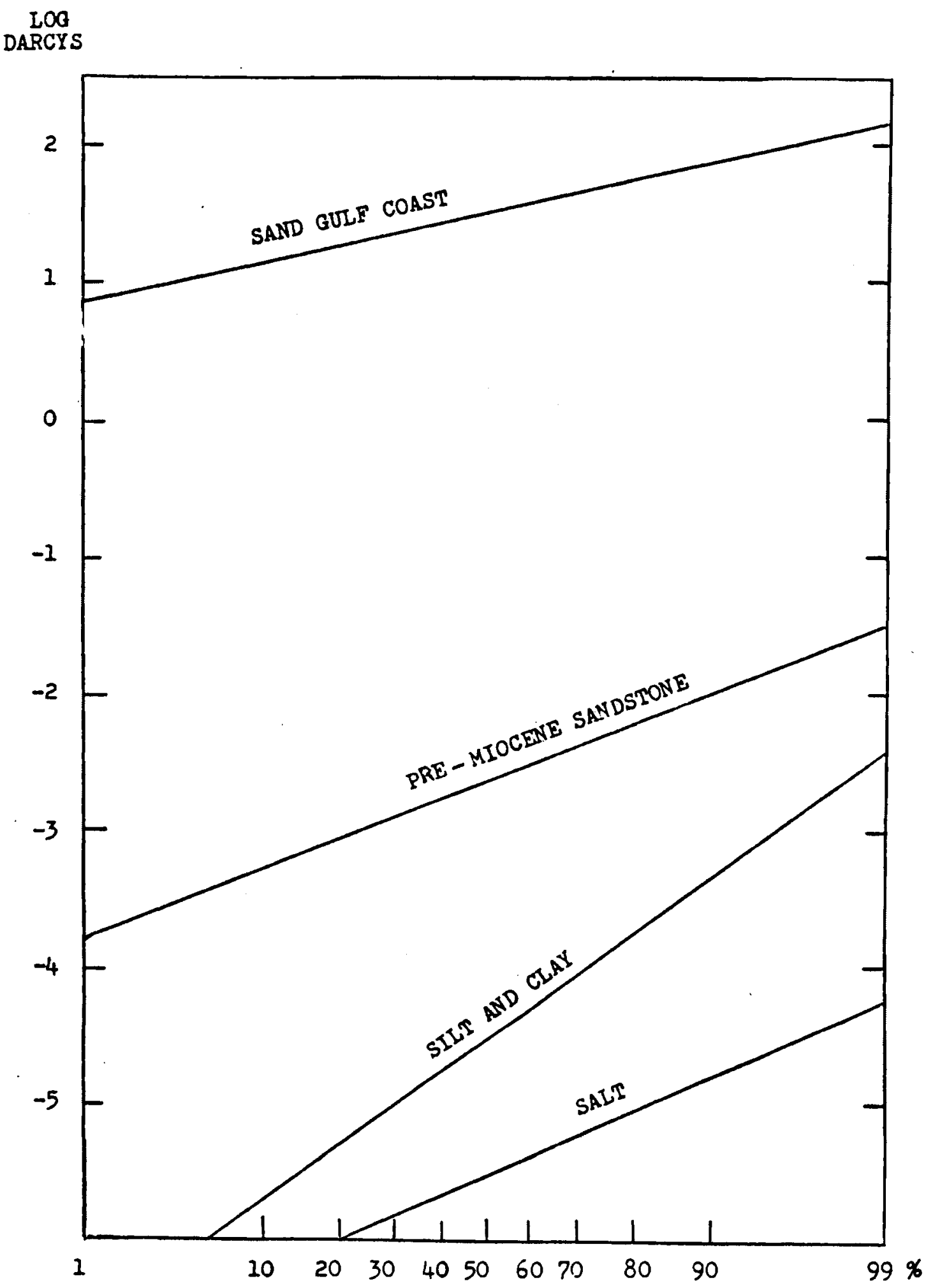

FIGURE 4. Log10-Probability Distributions of Permeabilities of Various Sedimentary Materials near Interior Gulf Coast Salt Domes 
never be used for studies of actual repository sites. The "Gulf Coast sands" of the figure are typical of the coarse to medium sands of Miocene, Pliocene, and Pleistocene age. Some of the "pre-Miocene sandstones" are more permeable than the diagram indicates. This statement is particularly true for the Carrizo aquifer and parts of the Wilcox aquifer. Permeabilities of these aquifers are about one order of magnitude less than the permeability of the "Gulf Coast sands." Due to lack of data in critical areas, the pre-Miocene aquifer trend line for the Carrizo and Wilcox aquifers was not drawn, but its slope is probably only slightly greater than the trend for "Gulf Coast sands."

Layers of sedimentary materials are shown schematically in Figure 3 as homogeneous units. This representation is $f$ ar from accurate, because all units have lenses and discontinuous layers of other lithologic types. In general, upper Cenozoic sediments are more heterogeneous than the older sediments. Approximate distributions of thicknesses of Miocene and younger sedimentary layers are summarized in Figure 5. These data should prove useful if judgements are to be made concerning the effects of fault offsets. For example, an offset of only 2 meters would place most sand lenses opposite clay and silt beds. Under most circumstances, the local transmissivity would be great ly reduced.

Effective porosities of the most permeable sands will be from 25 to $35 \%$. Those of the semi-indurated sandstone aquifers will generally be between 15 and $25 \%$. Field data are almost entirely lacking on dispersivity, but judging from a few values given by Borg et al. (1976) for sedimentary materials in other regions, longitudinal dispersivity for both nonindurated and indurated sands could be between 15 and 35 meters. Transverse dispersivity will, perhaps, vary between 5 and 50 meters.

Lowering of sea level will not drastically alter the heads in aquifers 100 to 200 miles inland. Because of the shallow coastal waters, the shoreline will move far to the south as sea level drops. Due to the fact that the increased distance of travel will partially compensate for the head differences between the salt domes and the new shoreline, the total hydraulic gradients in the regional aquifers should not be increased by more than about 
METERS

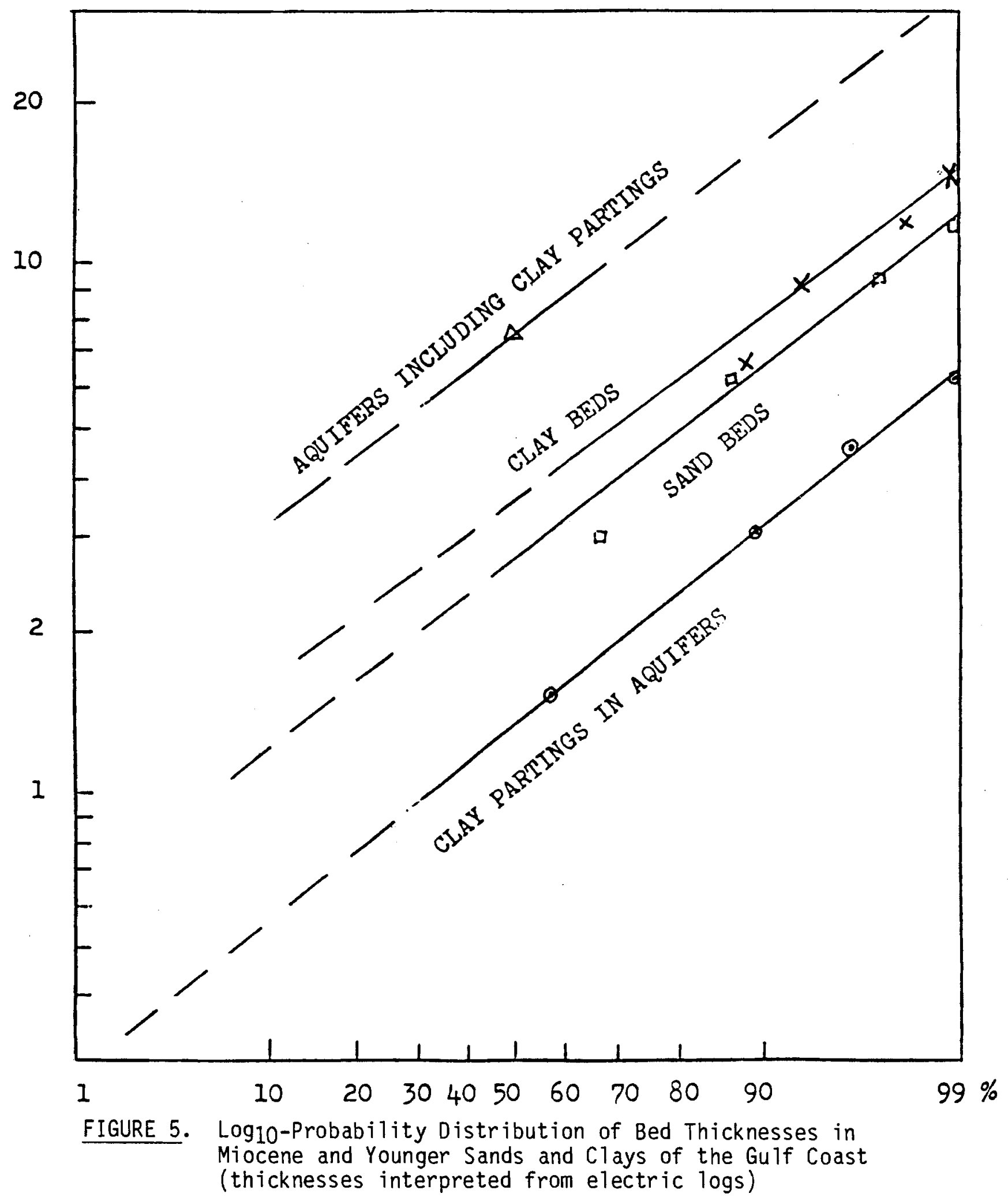


$30 \%$. However, the local aquifers at and near the surface could have their hydraulic gradients increased up to a maximum of about $100 \%$ before the water table essentially rises to the land surface. Thus, with an increase in precipitation, aquifers below a few hundred feet in depth will not be affected very much. However, ground-water circulation in permeable zones less than 100 feet in depth could experience a doubling of hydraulic gradients, and therefore a doubling of velocities, if rainfall is tripled (which is an unlikely condition).

Similarly, erosion could lower local base levels by about 50 feet. Base level lowering due to erosion has occurred several times during the Pleistocene. This erosion would provide head drops sufficient to increase hydraulic gradients in near-surface aquifers by 40 to $60 \%$. Surface erosion will probably affect gradients in aquifers below a few hundred feet by less than $10 \%$.

A drastic decrease in precipitation would decrease all hydraulic gradients, unless a decrease in evapotranspiration occurs at the same time. Local near-surface aquifers could experience decreases of hydraulic gradients of as much as $100 \%$ if precipitation dropped to half the present normal values. Deep aquifers would be affected far less.

If all ice caps were to melt, ocean levels would rise to cover most of the coastal salt domes. If this inundation happened, all hydraulic gradients would be reduced to very low values, perhaps lower than 0.0005 .

\section{BEDDED SALT OF THE SOUTHWEST}

Salt of Permian age is widespread in the subsurface of Kansas, Oklahoma, Colorado, Texas and New Mexico. Redbeds, dolomite, shale and abundant anhydrite are associated with salt. The general succession in southeastern New Mexico is shown in Figure 6. The arrows indicate possible flow paths of ground water if the containment is breached. In this area, several hundred feet of salt are buried at a favorable depth for a nuclear waste repository. Recent drilling by Sandia Corporation at the 1978 WIPP site, for example, penetrated about 600 feet of almost pure salt. However, the formation 
HORIZONTAL HYDRAULIC GRADIENT 0.005

\begin{tabular}{|l||l|}
\hline & $\begin{array}{l}\text { REDBEDS } \\
\text { SOME DOLOMITE AQUIFER }\end{array}$ \\
\hline SALT SOME ANHYDRITE \\
ANHYDRITE SOME SALT \\
SANDSTONE SOME LIMESTONE \\
\hline
\end{tabular}

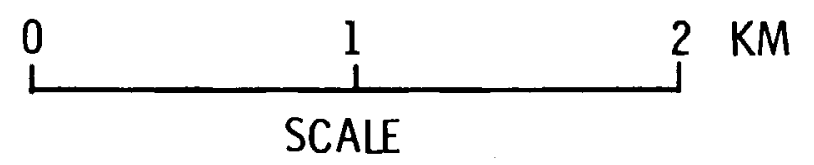

FIGURE 6. Cross Section Through a Possible Nuclear Repository in Southeastern New Mexico (horizontal and vertical scales are identical) 
actually consisted of about 63 individual beds of salt, along with 62 thin partings of impure salt mixed with anhydrite, polyhalite, sylvite, and other minerals. The median thickness of the almost pure salt beds was only 4 feet and the maximum was about 28 feet. Thicknesses of partings were generally less than 2 feet.

Few aquifers exist in southeastern New Mexico. The Rustler Formation, which overlies the thick salt, has a thin (10 to 40 feet) dolomite aquifer called the Culebra aquifer. Water in this aquifer is generally brackish. The Delaware Mountain Group has several sandstone beds, of which the uppermost Bell Canyon Formation is most important. This formation lies about 1500 feet beneath the Salado Formation, which contains the salt. The Bell Canyon Formation contains saline water. A very general geologic section in the southeastern part of New Mexico is shown in Figure 6.

Human intrusion and/or massive solution collapse in the salt appear to be the most likely forms of containment failure. If this containment failure were to take place under present climatic conditions in southeastern New Mexico, water from the Culebra aquifer might slowly fill the repository. The water might then continue to flow into the repository on the upgradient side and out on the downgradient side. This slow flushing of the repository could go on almost indefinitely, without any water appearing at the ground surface. It is difficult to visualize any mechanism, other than a very large meteorite impact, which would cause a breach into the underlying Bell Canyon Formation.

Representative effective porosities for the Culebra aquifer would range from about 5 to $15 \%$ with an average of about 10\%. Representative permeabilities are shown in Figure 7. Regional hydraulic gradients in the Culebra average about 0.002 but may locally be as low as 0.0005 or as high as 0.01 . Near the WIPP site, the maximum gradient in the Culebra aquifer is almost 0.005 . Longitudinal dispersivity is 38.1 meters, as determined from one field test in the Culebra dolomite aquifer near the Gnome nuclear detonation. Transverse dispersivity values might be approximately the same as longitudinal dispersivities, although they have not been measured.

Climatic changes could have dramatic effects on the ground-water regimen. Shallow, discontinuous bodies of late Cenozoic alluvium and dune sand could 


\section{LOG \\ DARCYS}

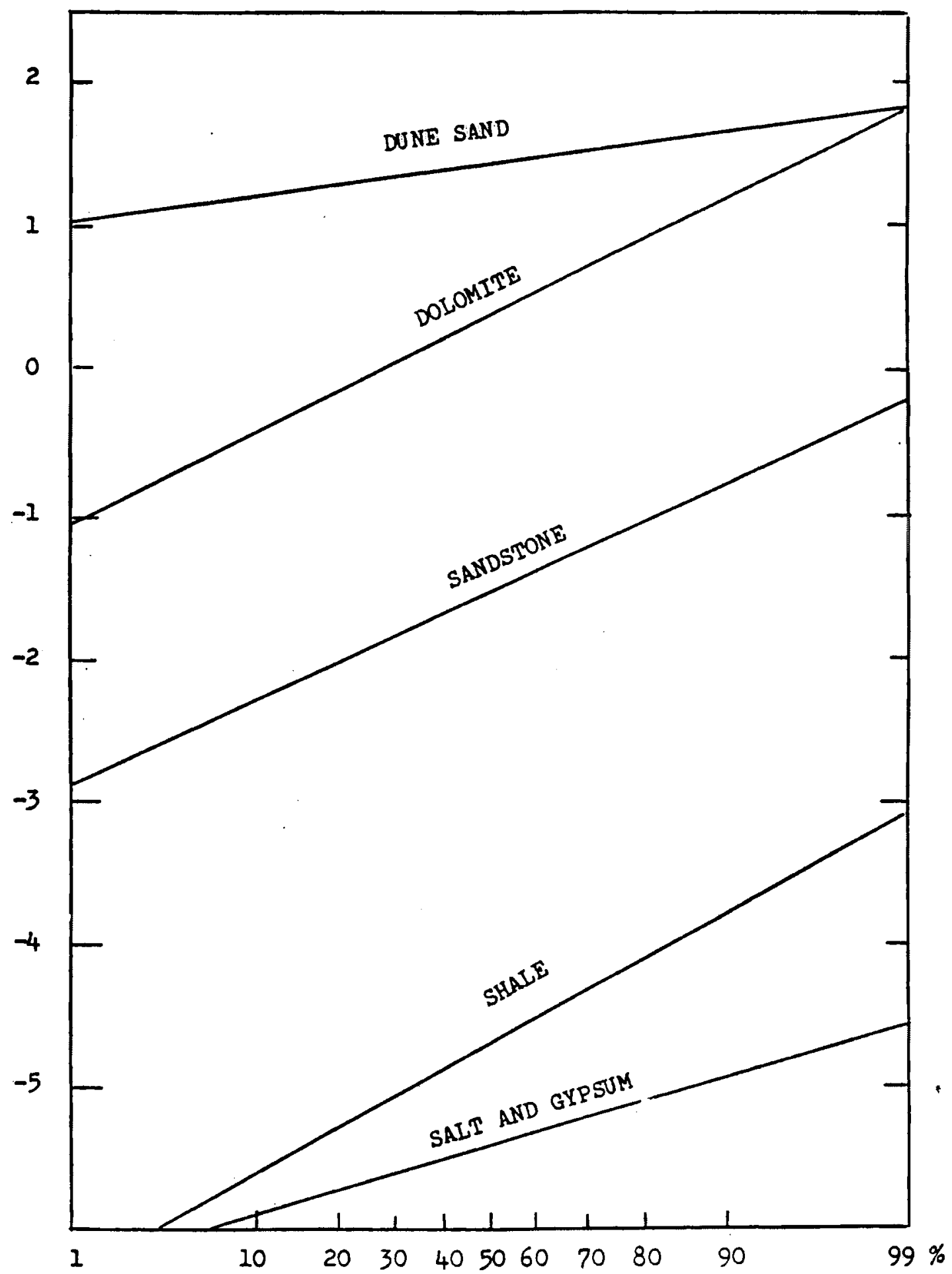

FIGURE 7. Log10-Probability Distributions of Permeabilities of Various Sedimentary Materials in Southeastern New Mexico 
become saturated if rainfall tripled or if evapotranspiration were reduced to very low values. Local recharge to the Culebra aquifer, however, would be small. A long period, perhaps hundreds of years, would need to elapse before the slow recharge in the intake area to the north would bring the system into equilibrium. The average hydraulic gradients in the Culebra dolomite, for example, could be increased to about 0.007 , judging by the elevation of the discharge area near Malaga Bend on the Pecos River and the elevation of the probable recharge area to the north.

\section{SHALE IN THE BASIN AND RANGE PROVINCE}

Paleozoic shale is widespread in the central and eastern Basin and Range Province. In many localities, the "shale" is actually a slate or phyllite. In other localities it is a brittle, compact argillite. Comonly, thin beds of dolomite, limestone, and orthoquartzite are interbedded with the shale. Everywhere it is found, the shale has been faulted, folded, or deformed in some manner. The Eleana Formation on the Nevada Test Site has abundant argi1laceous materials and has been considered as a possible candidate for a repository site. Although it is known to be stratigraphically above Paleozoic carbonate rocks, its structural relation to the younger rocks is not everywhere known.

A hypothetical section through upper Paleozoic argillites is shown in Figure 8. The arrows indicate possible direction of ground-water migration in the case of a massive breach of the repository, which is shown schematically as an inverted "T". Regionally, fractured carbonate rocks form underdrains for the overlying rocks, so that vertical hydraulic gradients are, in many localities, much higher than horizontal gradients. This fact is indicated in Figure 8. Valleys in the Basin and Range Province are commonly filled with a few thousand feet of alluvium, lacustrine silts, and volcanic rocks. The alluvium is generally quite permeable compared with most of the pyroclastic rocks. In the Nevada Test Site, however, the alluvium is above the water table in almost all locations. 

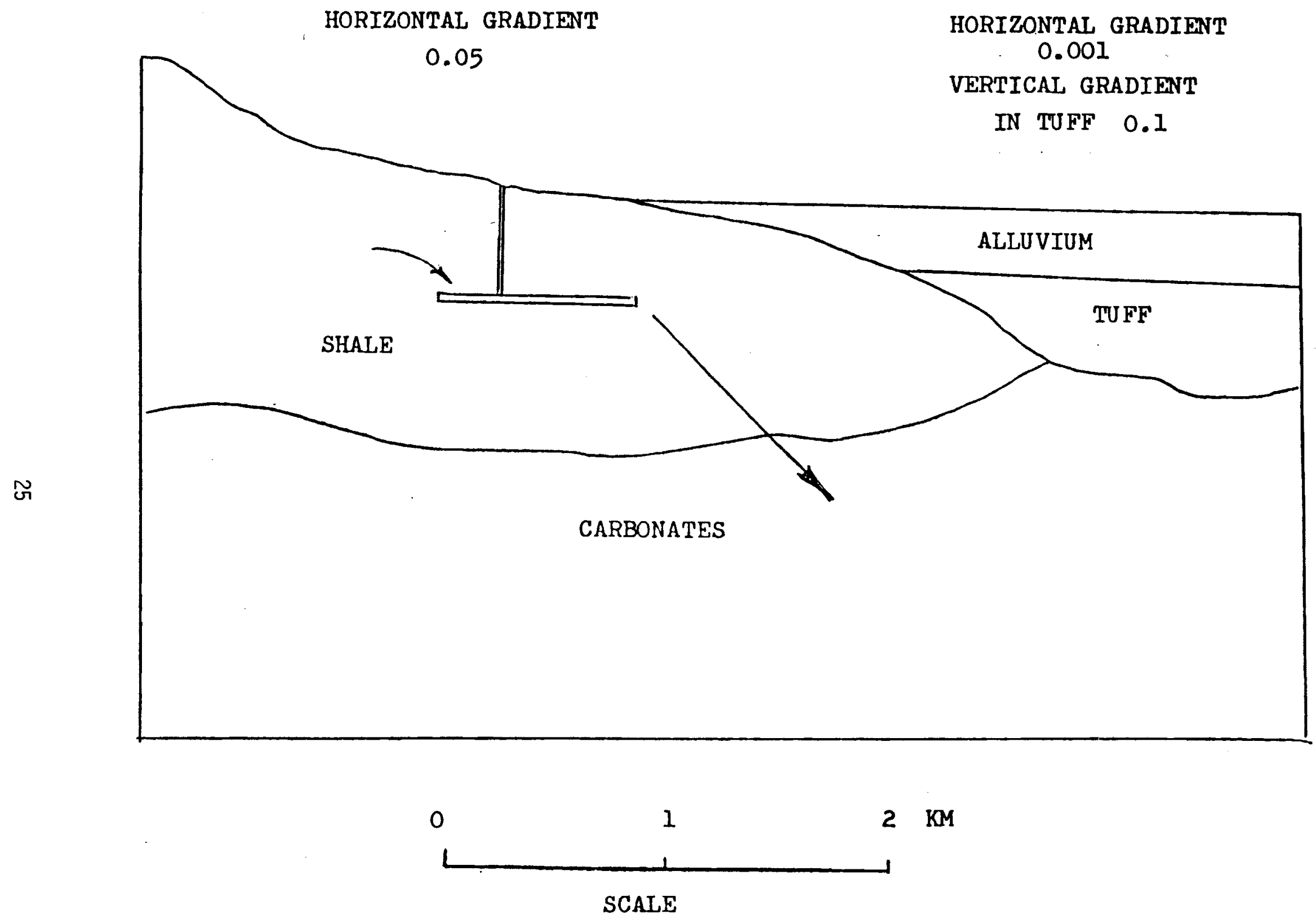

FIGURE 8. Hypothetical Cross Section Through Argillaceous Rocks in the Nevada Test Site 
Typical permeability values for rocks of the Basin and Range Province are shown in Figure 9. Effective porosity of the most permeable portions of the valley fill will be between 20 and $30 \%$. The effective porosity of the fractured carbonate rocks will be between 1 and $5 \%$, but it will be much higher in local solution openings. The effective porosity of fractured granite will generally be between 0.1 and $2 \%$, except in the weathered rock near the surface where values of 5 to $30 \%$ could be encountered. One field measurement of dispersivity of the carbonate rocks at the Nevada Test Site has been made (Borg et al. 1976). This measurement yielded a value of 15 meters for the longitudinal dispersivity.

Some geologists have considered future faulting to be a likely method of breaching the containment on the Nevada Test Site. If such a breach occurred, water would drain downward through the repository into the underlying carbonate aquifers, unless a drastic change in the ground-water regimen took place.

An increase in precipitation might increase local hydraulic gradients in less permeable rocks in the Basin and Range Province. In recharge areas of the larger circulation systems, such as the carbonate aquifers of the Nevada Test Site, water might tend to pond in closed topographic basins which are dry at the present time. The water might then be lost by evaporation. Recharge, therefore, might not increase in proportion to an increase of precipitation because of the very large increase of evaporation in the formerly dry lakebeds. If water levels $r$ ise so that permanent standing water appears in Yucca Flat, the total head drop between Yucca Flat and the regional discharge in Ash Meadows, some miles away, will increase by at least 1500 feet. The present head drop is only about 150 to 200 feet.

If Yucca Flat were flooded, the major part of the head drop would be in the tuff and not in the carbonate aquifer. A doubling of the present regional gradient in the carbonate aquifer might be caused by a drastic increase in precipitation in the region, but an increase of more than four-fold would appear to be highly unlikely. To predict more precise gradients, one would need to consider specific locations within the Nevada Test Site. A careful study of work by Winograd and Thordarson (1975) would also be needed. 


\section{DARCYS}

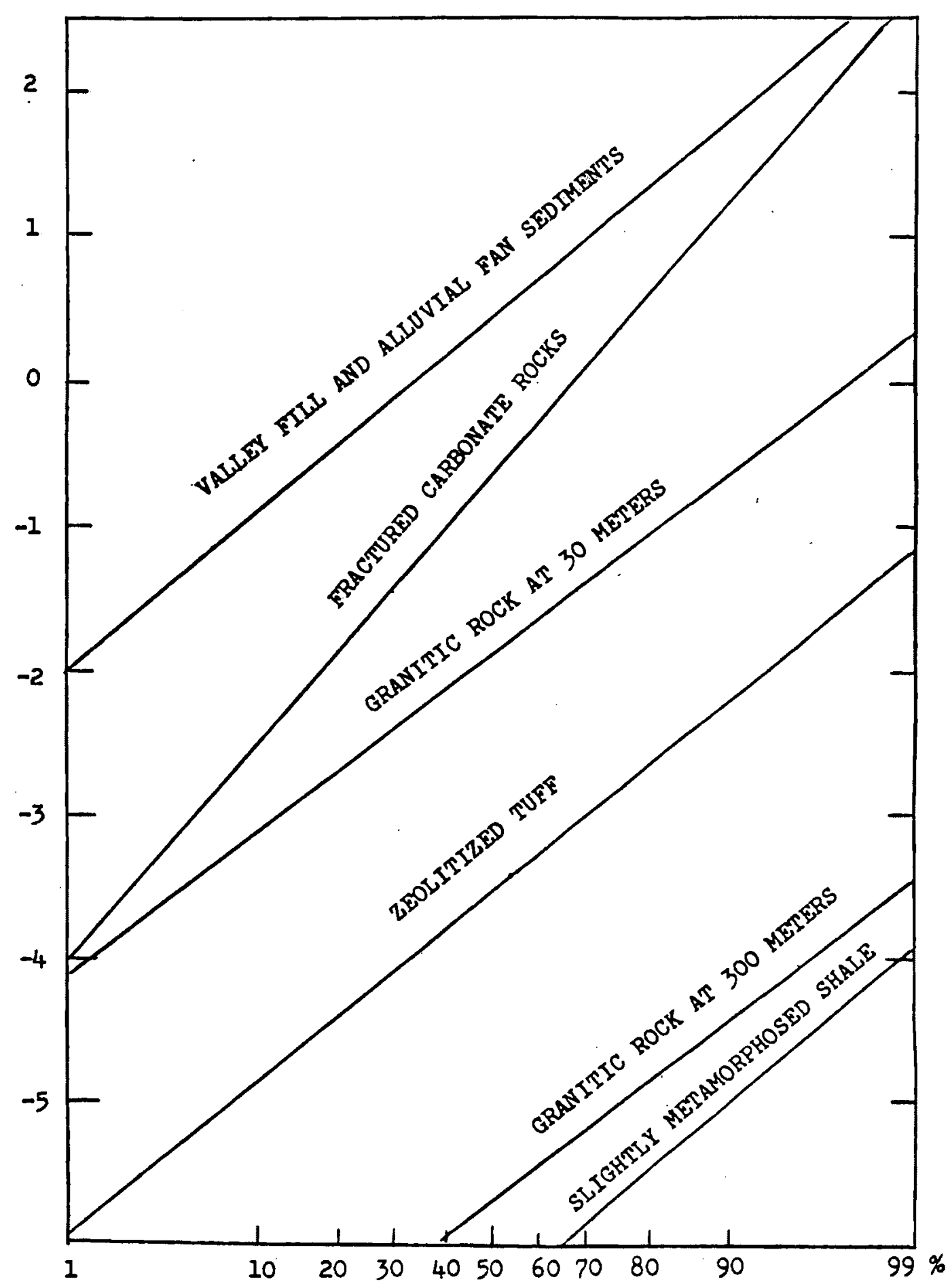

FIGURE 9. Log10-Probability Distributions of Permeabilities of Various Geologic Units in the Basin and Range Province in Southern Nevada 
GRANITIC STOCKS IN THE BASIN AND RANGE PROVINCE

Numerous Mesozoic and Early Cenozoic stocks exist in the Basin and Range Province. Many of these are faulted and associated with mineralization in surrounding rocks. As indicated in Figure 10, the hydraulic gradients are much 1 arger in the granitic rocks than in the carbonate rocks. This difference in gradient reflects, in part, a contrast of permeability of the two media. Arrows in Figure 10 indicate the possible direction of ground-water migration in the event of containment failure.

Most of the discussion in the previous section about shale also applies to granitic stocks. The major difference is that in a stock, the permeability and porosity will continue to decrease with depth, whereas lithologic changes in the sedimentary rocks could give rise to increases in permeability with depth.

Permeability of weathered granitic material near the land surface may be close to 1.0 darcy, and the effective porosity could be as large as $30 \%$. Both permeability and porosity decrease rapidly with depth, so that values of permeability shown in Figure 9 pertain at depths of 30 and 300 meters. Effective porosity at 30 meters would be close to $0.5 \%$, and at 300 meters it might be even less than $0.1 \%$. Field measurements of the dispersivity of granitic rocks have not been made. However, longitudinal and lateral dispersivities between 10 and 200 meters might be expected.

Experience in Western mines and tunnels suggests that, although the above generalities are valid, permeable fault zones filled with water can be encountered in granitic rocks at depths greater than 300 meters and in some places even greater than 1000 meters. Permeable zones at such depths are, nevertheless, quite rare, and their locations can commonly be predicted on the bas is of detailed geologic studies. 
HORIZONTAL GRADIENT
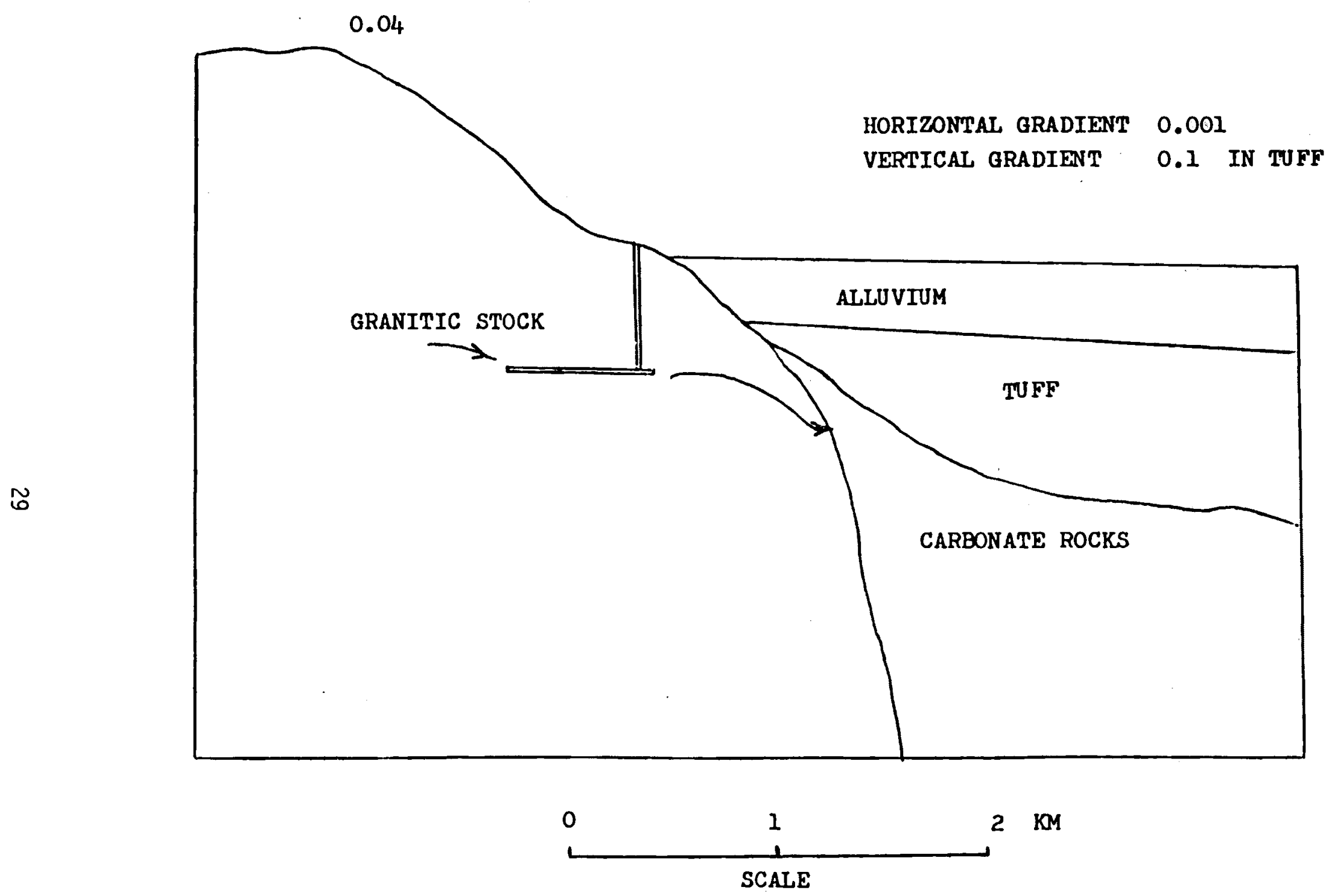

FIGURE 10. Cross Section Through a Hypothetical Nuclear Repository in a Granitic Stock, Basin and Range Province (Horizontal and Vertical Scales are Identical) 
HYDRAULIC FRACTURING

High differential hydraulic heads will produce stress fields which, when combined with tectonic and other stresses, could induce rock fracturing. Except in studies of possible mechanical failures of the repository cavity itself and of short-term meteorite impact and seismic stresses, hydraulic fracturing is judged to be of only minor importance in possible containment failure (at least for the regions discussed in this report). Virtually all natural changes should be slow enough to allow the system to approach steady state. Large local hydraulic gradients should not develop. Future hydraulic gradients in excess of about 0.3 are not expected, except in areas near the repository face and in response to meteorite impacts and earthquakes. The highest gradients would be in materials of low natural permeability, such as the tuff beds in the Nevada Test Site.

For certain calculations, the total hydraulic head could be important. For almost all purposes, the elevation difference between the subsurface point of interest and the land surface in the area of aquifer recharge should be taken as the maximum future hydraulic head. In the Gulf coast, the future changes of head will be small, because the water table is near the surface everywhere. In the Nevada Test Site, if rainfall were increased many-fold, the future head increase could amount to as much as 1500 feet. If rainfall is reduced in the future, the head drop in the future could be about 200 feet in the same area.

NOTE: Hydraulic head is defined as:

$$
h=z+\frac{p}{\gamma}
$$

where

$$
\begin{aligned}
& h=\text { hydraulic head } \\
& z=\text { elevation at the point of interest } \\
& p=\text { pressure at the point of interest } \\
& \gamma=\text { specific weight of the water. }
\end{aligned}
$$




\section{REFERENCES}

Bennion, D. W. and J. C. Griffiths. 1966. "A Stochastic Model for Predicting Variations in Reservoir Rock Properties." Trans. Am. Inst. Mining Met. Engrs., $237: 9-16$.

Borg, I. Y. et a1. 1976. Information Pertinent to the Migration of Radionuclides in Ground Water at the Nevada Test Site, Part 1: Review and Analysis of Existing Information. UCRL-52078, Part 1, $216 \mathrm{pp.}$ Lawrence Livermore Laboratory, University of California, Berkeley, CA.

Borg, I. Y. et a1. 1976. Information Pertinent to the Migration of Radionuclides in Ground Water at the Nevada Test Site, Part 2: Annotated Bibliography. UCRL-52078, Part 2, 112 pp. Lawrence Livermore Laboratory, University of Cal ifornia, Berkeley, CA.

Clar, M. M. 1972. "Collapse Fissures Along the Coyote Creek Fault," In The Borrego Mountain Earthquake of April 9, 1968. U.S. Geological Survey Prof. Paper 787, pp. 190-207.

Classen, H. C. 1978. Hydrologic Processes and Radionuclide Distribution in a Cavity and Chimney Produced by the Cannikin Nuclear Explosion, Amchitka Island, Alaska. U.S. Geological Survey Prof. Paper 712-D, 28 pp.

Cooper, J. B. and V. M. Glanzman. 1971. Geohydrology of Project Gnome Site, Eddy County, New Mexico. U.S. Geological Survey Prof. Paper 712-A, 24 pp.

Davis, S. N. 1969. "Porosity and Permeability of Natural Materials," In Flow Through Porous Media, pp. 53-89, R. J. M. DeWiest, editor. Academic Press, New York.

Davis, S. N. 1978. "Origin of Earth Fissures." Geol. Soc. America Abstracts with Program, 10(3):102.

Dinwiddie, G. A. and J. E. Weir, Jr. 1978. Hydrologic Investigations of the Eleana Formation. In National Waste Terminal Storage Program Progress Report, J. M. Asher, editor: Office of Waste Isolation, Union Carbide Corporation, Report Y/OWI-9, p. 43-49.

Gonzales, D. D. and L. E. Wollitz. 1972. "Hydrological Effects of the Cannikin Event." Seismological Soc. of America Bu11., 62:1527-1542.

Houser, F. N. 1970. A Summary of Information and Ideas Regarding Sinks and Collapse, Nevada Test Site. U.S. Geological Survey Open-File Report, NTS-216, USGS-474-41, $129 \mathrm{p}$. 
Johnson, A. I. and A. H. Ludwig. 1965. Hydrologic and Physical Properties of Cores from Hydrologic Test Sites 1 and 2, Tatum Dome, Lamar County, Mississippi. U.S. Geological Survey Open-File Report, Technical Letter Dribble-40.

Kreitler, C. W., et al. 1977. "Hydrogeology of Gulf Coast Aquifers, Houston-Galveston Area, Texas." Gulf Coast Assoc. Geol. Sci. Trans., $27: 72-89$.

Mckeown, F. A., D. D. Dickey, and W. L. Ellis. 1969. Preliminary Report on the Geologic Effects of the Faultless Event: U.S. Geological Survey Open-File Report, Central Nevada-16, USGS-474-65, $20 \mathrm{p}$.

Maldonado, F. 1977. Summary of the Geology and Physical Properties of the Climax Stock, Nevada Test Site. U.S. Geological Survey Open-File Report $77-356$.

Manger, G. E. 1963. "Porosity and Bulk Density of Sedimentary Rocks." U.S. Geological Survey Bull. 1144-E.

Martinez, J. D., et al. 1977. An Investigation of the Utility of Gulf Coast Salt Domes for the Storage or Disposal of Radioactive Wastes. Institute for Environmental Studies, Louisiana State University, Baton Rouge, OWI Progress Report, Y/OWI/SUB-4112/37, $468 \mathrm{p}$.

Mundi, E. K. and J. R. Wallace. 1973. "On the Permeability of Some Fractured Crystalline Rocks." Assoc. Engineering Geol. Bu11, 10:299-312.

Rats, M. V. and S. N. Chernyashov. 1967. "Statistical Aspect of the Problem on the Permeability of the Jointy Rocks." In Hydrology of the Fractured Rocks. UNESCO Special Publication and International AsSOC. Sci. Hydrology Publication, 1:227-236.

Sanya1, S. K., K. A. Kvenvolden, and S. S. Marsden. 1971. "Permeabilities of Precambrian Onverwacht Cherts and Other Low Permeability Rocks." Nature, $232(5309): 325-327$.

Siddiqui, S. H. and R. R. Parizek. 1971. "Hydrogeologic Factors Influencing Well Yields in Folded and Faulted Carbonate Rocks in Central

Pennsylvania." Water Resources Research, 7:1295-1312.

Stewart, G. W. 1966. Drilled Water Wells in New Hampshire. New Hampshire Mineral Resources Survey, Part 20, $58 \mathrm{p}$.

U.S. Geological Survey. 1976. Field Trip to the Nevada Test Site. U.S. Geological Survey Open-File Report 76-313, 64 p. 
Waiker, G. E. 1962. Ground Water in the Climax Stock, Nevada Test Site, Nye County, Nevada. U.S. Geological Survey TEI-813, Open-File Report, 48 p.

Winograd, I. J. 1971. "Hydrogeology of Ash Flow Tuff: A Preliminary Statement." Water Resources Research, 7:994-1006.

Winograd, I. J. and W. Thordarson. 1968. "Structural Control of Ground-Water Movement in Miogeosynclinal Rocks of South-Central Nevada." In Nevada Test Site, E. B. Eckel, ed. Geol. Soc. America Memoir 110, pp. 35-49.

Winograd, I. J. and W. Thordarson. 1975. Hydrogeologic and Hydrochemical

Framework, South-Central Great Basin, Nevada-California, with Special Reference to the Nevada Test Site. U.S. Geological Survey Prof. Paper $712-\mathrm{C}, 126 \mathrm{p}$. 


\section{DISTRIBUTION}

No. of

Copies

OFFSITE

2 Argonne National Laboratory

Reference Library

9800 S. Cass Ave.

Argonne, IL 60439

Battelle Memorial Institute

Office of Nuclear Waste

Isolation

505 King Ave.

Columbus, $\mathrm{OH} 43201$

Attn: Bever ly Rawles

2 Brookhaven National Laboratory

Reference Section

Information Division

Upton, Long Island, NY 11973

27 DOE Technical Information Center

John Bird

Geology Department

Cornell University

Ithaca, NY 14853

John Bredehoeft

U.S. Geological Survey

Reston, VA 22092

Robert Budnitz

U.S. Nuclear Regulatory

Commission

Washington DC 29545

Colin Bull

Office of the Dean

College of Math and Physical

Sciences

Ohio State University

164 W. 17th Ave.

Columbus, $\mathrm{OH} 43201$
No. of

Copies

Harry C. Burkholder

Office of Nuclear Waste

Isolation

Battelle Memorial Institute

505 King Ave.

Columbus, $\mathrm{OH} 43201$

Jim Campbell

T39

Division 5413

Sandia Labs

Albuquerque, NM 87185

20 Wayne A. Carbiener

Office of Nuclear Waste

Isolation

Battelle Memorial Institute

505 King Avenue

Columbus, $\mathrm{OH} 43201$

A. A. Churm

DOE Patent Division

9800 So. Cass Ave.

Argonne, IL 60439

H. Clyde Claiborne

Oak Ridge National Laboratory

P.0. Box X, Building 3017

Oak Ridge, TN 37830

James Clark

c/o Eugene Vetter

Route 2, Box 70

Shawano, WI 54166

Neville G. W. Cook

Dept. of Materials Science and Mineral Engineering

Hearst Mining Building

University of California

Berkeley

Berkeley, CA 94720 
No. of

Copies

Carl R. Cooley

DOE Office of Waste Management

Washington DC 20545

Howard A. Coombs

Department of Geological Sciences

University of Washington

Seattle, WA 98194

James W. Crosby III

1467 Alpowa

Moscow, ID 83843

Bruce Crowe

Geological Research Group, G-6

Los Alamos Scientific

Laboratory

P.0. Box 1663

Los Alamos, NM 87545

Jared Davis

27 Nuclear Regulatory Commission

Washington DC 20555

10 Stanley N. Davis

6540 W. Box Canyon Drive

Tucson, AZ 85705

G. L. DeBuchananne

U.S. Geological Survey

Reston, VA 22092

Terry Donich

Lawrence Livermore Laboratory

P.0. Box 808

Livermore, CA 94550

James Duguid

Office of Nuclear Waste

Isolation

Battelle Memorial Institute

Columbus, $\mathrm{OH} 43201$
No. of

Copies

Don Easterbrook

Western Washington University

Bellingham, WA 98225

Dan Egan

U.S. Environmental Protection Agency

Washington DC 20545

Environmental Protection Agency

Office of Radiation Programs

Technical Assessment Division Aw559

Washington DC 20460

J. G. Feinstein

NUS Corporation

4 Research Place

Rockville, MD 20850

Graham E. Fogg

Bureau of Economic Geology

The University of Texas Austin

University Station, Box $X$

Austin, TX 78712

Robert M. Garrells

Dept. of Geologic Sciences

Northwestern University

Evanston, IL 60201

Raymond D. Gastil

Freedom House

20 W. 40th St.

New York, NY 10018

Earnest Gloyna

National Academy of Sciences

University of Texas

Austin, TX 78712

George Griswold

Tecolote Corporation

531 Wagon Train Drive SE

Albuquerque, NM 87123 
No. of

Copies

Charles R. Hadlock

Arthur D. Little, Inc.

Acorn Park

Cambridge, MA 02140

Colin A. Heath

DOE Division of Waste

Management

Washington DC 20545

William M. Hewitt

Office of Nuclear Waste

Isolation

Battelle Memorial Institute

505 King Ave.

Columbus, $\mathrm{OH} 43201$

John M. Hills

818 Kerbey Ave.

El Paso, TX 79902

Peter L. Hofmann

Office of Nuclear Waste

Isolation

Battelle Memorial Institute

505 King Avenue

Columbus, $\mathrm{OH} 43201$

John T. Holloway

Committee on Radioactive Waste

Management $\mathrm{JH}-826$

National Academy of Sciences

2101 Constitution Ave. NW

Washington DC 20418

Vojin Joksimovic

General Atomic Company

P.0. Box 81608

San Diego, CA 92138

Lou is S. Karably

Law Engineering

2749 Delk Road SE

Marietta, GA 30067
No. of

Copies

R. F. Kaufman

Evaluation Branch

Office of Radiation Programs

U.S. Environmental Protection Agency

P.0. Box 18416

Las Vegas, NV 89114

Ralph Kehle

7800 Shoul Creek Blvd.

Suite 270 S

Aust in, TX 78757

Muzaffer Kehnemuyi

Office of Nuclear Waste

Isolation

Battelle Memorial Institute

505 King Ave.

Columbus, $\mathrm{OH} 43201$

John F. Kircher

Office of Nuclear Waste

Isolation

Battelle Memorial Institute

$505 \mathrm{King}$ Ave.

Columbus, $\mathrm{OH} 43201$

Charles Koplick

The Analytic Sciences Corp. 6 Jacob Way

Reading, MA 01867

Charles W. Kreitler

Texas Bureau of Economic Geology

University Station, Box $X$

Austin, TX 78712

George K. Kukla

Lamont-Doherty Geological

Observatory

Palisades, NY 10964

Donald H. Kupfer

Department of Geology

Louisianna State University

Baton Rouge, LA 70803 
No. of

Copies

James G. LaBastie

Law Engineering and Testing Co. 2749 Delk Road SE

Marietta, GA 30067

Ronald B. Lantz

INTERA Environmental

Consultants, Inc.

11511 Katy Freeway

Houston, TX 77079

2 Lawrence Berkeley Laboratory

Reference Library

University of $\mathrm{Cal}$ ifornia

Berkeley, CA 94720

2 Lawrence Livermore Laboratory

Reference Library

P.0. Box 808

Livermore, CA 94550

Darre 11 e I. Leap

USGS, WRD, MS416

Box 25046

Denver Federal Center

Denver, CO 80225

Richard Lincoln

Sandia Laboratories

N.N.W.S.I.

NTS Technical Overview

Division 4538

Albuquerque, NM 87185

Stanley E. Logan

Nuc lear Waste Management

Program

Los Alamos Technical

Associates, Inc.

P.0. Box 410

Los Alamos, NM 87554

Ear 1 M. Lovejoy

4400 Fairview Road

Reno, NV 89511
No. of

Copies

S. J. Mara

SRI International.

333 Ravenswood Avenue

Men lo Park, CA 94025

Peter D. Mattison

Arthur D. Little, Inc.

Acorn Park

Cambridge, MA 02140

W. C. McClain

Oak Ridge National Laboratory

P.Q. Box $X$

Oak Ridge, TN 37830

John T. McGinnis

Office of Nuclear Waste Isolation

Battelle Memorial Institute

505 King Ave.

Columbus, $\mathrm{OH} 43201$

Sheldon Meyers

DOE Office of Nuclear Waste

Management

Washington DC 20545

Peter A. Mote

Bechtel, Inc.

P.0. Box 3965

San Francisco, CA 94105

2 Barry Naft

NUS Corporation

4 Research Place

Rockville, MD 20805

J. 0. Neff

Department of Energy

Columbus Program Office

505 King Ave.

Columbus, $\mathrm{OH} 43201$

Robert H. Neil

State of New Mexico

Environmental Evaluation Group

P.0. Box 968

Santa Fe, NM 87503 
No. of

Copies

Ivars Neretnieks

Earth Science Division

Lawrence Berkeley Laboratory

University of California

Berkeley, CA 94720

2 Neil Norman

Environmental Sciences Dept.

Bechtel National, Inc.

P.0. Box 3965

San Francisco, CA 94105

2 Los Alamos Scientific Laboratory Reference Library

P.0. Box 1663

Los Alamos, NM 87544

2 Oak Ridge National Laboratory

Central Research Library

Document Reference Section

Oak Ridge, TN 37830

Suresh B. Pahwar

INTERA Environmental

Consultants, Inc.

11511 Katy Freeway, Suite 630

Houston, TX 77079

Frank L. Parker

Dept. of Environmental

Engineering

Vanderbilt University

Nashville, TN 37235

James Pearson

INTERA Environmental

Consultants, Inc.

11511 Katy Freeway, Suite 630

Houston, TX 77079

George F. Pinder

Dept. of Civil Engineering

Stanford University

Stanford, CA 94305
No. of

Copies

Larry Ramspott

Technical Program officer

Lawrence Livermore Laboratory

P.0. Box 808

Livermore, CA 94550

Linda Robinson

NUS Corporation

4 Research Place

Rockville, MD 20850

Savannah River Laboratory

Reference Library

Aiken, SC 29801

Maurice L. Schwartz

Department of Geology

Western Washington University

Bellingham, WA 98225

Genevieve Segol

Bechtel, Inc.

P.0. Box 3965

San Francisco, CA 94105

Herb Shaw

U.S. Geological Survey

Mail Stop 18

345 Middlefield Road

Men lo Park, CA 94025

Dillard B. Shipler

Office of Nuclear Waste Isolation

Battelle Memorial Institute

505 King Ave.

Columbus, $\mathrm{OH} 43201$

James N. Siltanen

General Atomic Company

P.0. Box 81608

San Diego, CA 92138

George M. Slaughter

Law Engineering and Testing Co.

2749 Delk Road SE

Marietta, GA 30067 
No. of

Copies

Barry J. Smernoff

Hudson Institute

Quaker Ridge Road

Croton-On-Hudson, NY 10520

Terry Ste inborn

Lawrence Livermore Laboratories

P.0. Box 808

Livermore, CA 94550

Howard P. Stephens

Sandia Laboratories

N.N.W.S.I.

Division 4538

Albuquerque, NM 87185

James I. Stevens

Arthur D. Little, Inc.

Acorn Park

Cambridge, MA 02140

David B. Stewart

U.S. Geological Survey National Center 959

Reston, VA 22092

Robert L. Thoms

Institute for Environmental

Studies

Louisianna State University

Baton Rouge, LA 70803

Newe 11 Trask

U.S. Department of the Interior Geological Survey

Mail Stop 929

Reston, VA 22092

W. S. Twenhofel

USGS

Mail Stop 954

Denver, CO 80225

Maurice D. Veatch 6834 - 51st Ave. NE

Seattle, WA 98115
No. of

Copies

W. Weart

Division 1140

Sandia Laboratories

Albuquerque, NM 87115

Lawrence Wight

TERA

2150 Shaltuck Ave.

Berkeley, CA 94704

Charlie Wilson

Earth Sciences Division

Lawrence Livermore Laboratory

Building 90

Berkeley, CA 94720

Paul Witherspoon

Earth Sciences Division

Lawrence Livermore Laboratory

Building 90

Berkeley, CA 94720

\section{FOREIGN}

D'Allessandro Avogadro

Commission of European Communities

Joint Rersearch Centre

I-21020 Ispra (Varese)

ITALY

K. H. Hubenthal

Bundesministerium fur Forschung und Technologie

Stressemanistrasse 2

Postfach 200706

D-5300 Bonn

F.R. Of GERMANY

Leif Carlsson

Geological Survey of Sweden

Bredgrand 4

S-753 20 UPPSALA

$018 / 15 \quad 56 \quad 40$

SWEDEN 
No. of

Copies

Center for Atomic Energy

Documentation (ZAED)

ATTN: Dr. Bell

Postfach 3640

D-7500 Kar lsruhe

$F . R$. of GERMANY

Ken Dornuth

Atomic Energy Canada Ltd.

Whiteshell Nuclear Research

Establishment

Pinawa, Manitoba ROE $1 L 0$

CANADA

F. Gera

Nuc lear Energy Agency/OECD

38 boulevard Suchet

F-75016 Paris

FRANCE

2 INIS Clearinghouse

International Atomic Energy Agency

P.0. Box 590

A-1011, Vienna

AUSTRIA

Klaus Kuhn

Institut fur Tiefagerung

Wissenschaft liche Abteilung

Berliner Strasse 2

D-3392 Clausthal - Zellerfeld

$F . R$. of GERMANY

Hans W. Levi

Hahn-Meitner-Institut fur Kernforschung

Glienicker Strasse 100

D-1000 Berlin 39

$F . R$. of GERMANY

Library

Studsvik Energiteknik $A B$

S-611 01 Nykoping

SWEDEN
No. of

Copies

\author{
Takehico Ngamatsu \\ Geologist \\ Chief Representative Vancouver \\ office \\ Mitsubishi Metal Corporation \\ 78 Granville Square \\ 200 Granville Street \\ Vancouver, BC V6C 154 \\ CANADA \\ Franz Peter Oesterle \\ Physikalisch-Chemische \\ Bundesanstalt \\ Bundesallee 100 \\ D-3300 Braunschweig \\ $F . R$. of GERMANY \\ F. P. Sargent \\ Atomic Energy of Canada, Ltd. \\ Whiteshell Nuclear Research \\ Establishment \\ Pinawa, Manitoba ROE 1LO \\ CANADA \\ Noritaka Sato \\ Chief Geologist, Domestic \\ Exploration \& Nuclear \\ Resources \\ Mitsubishi Metal Corporation \\ 1-5-2 Ohte-Machi \\ Chiyoda-Ku, tokyo \\ JAPAN
}

Egbert Schapermeier

Battelle-Institute e.v.

Am Romerhof 35

D-6000 Frankfurt am Main 90

$F$. R. of GERMANY

Tjalle Vandergraff

Atomic Energy of Canada Limited

Whiteshe 11 Nuclear Research

Establishment

Pinawa, Manitoba ROE 1LO

CANADA 
No. of

Copies

ONSITE

5 Department of Energy

0. J. Elgert

H. E. Ransom

J. J. Schreiber

D. J. Squires

F. R. Standerfer

7 Rockwell Hanford Operations

R. L. Biggerstaff

D. J. Brown

R. A. Deju

G. S. Hunt

R. E. I saacson

G. L. Jones

Rockwell Document Control

45 Pacific Northwest Laboratories

E. M. Arnold

G. L. Benson
No. of

Copies

A. Brandstetter (10)

R. A. Craig

W. J. Deutsch

F. H. Dove

M. A. Harwell

M. R. Kreiter

J. W. Lindberg

R. F. McCallum

K. S. Murthy

G. M. Petrie

A. M. Platt

J. F. Relyea

B. L. Scott

J. G. Stephan

J. A. Stottlemyre

R. W. Wallace

J. T. Zellmer

Technical Information Library (5)

Publishing Coordination $\mathrm{SH}(2)$

Water and Land Resources

Department Library (10) 